\title{
Sensory Activation of Command Cells for Locomotion and Modulatory Mechanisms: Lessons from Lampreys
}

\author{
Gheylen Daghfous ${ }^{1,2}$, Warren W. Green ${ }^{3 \dagger}$, Simon T. Alford ${ }^{4}$, Barbara S. Zielinski ${ }^{3}$ \\ and Réjean Dubuc ${ }^{1,2 *}$
}

${ }^{1}$ Groupe de Recherche en Activité Physique Adaptée, Département des Sciences de l'Activité Physique, Université du Québec à Montréal, Montréal, QC, Canada, ${ }^{2}$ Groupe de Recherche sur le Système Nerveux Central, Département de Neurosciences, Université de Montréal, Montréal, QC, Canada, ${ }^{3}$ Department of Biological Sciences and Great Lakes Institute for Environmental Research, University of Windsor, Windsor, ON, Canada, ${ }^{4}$ Laboratory of Integrative Neuroscience, Department of Biological Sciences, University of Illinois at Chicago, Chicago, IL, USA

Sensorimotor transformation is one of the most fundamental and ubiquitous functions of the central nervous system (CNS). Although the general organization of the locomotor neural circuitry is relatively well understood, less is known about its activation by sensory inputs and its modulation. Utilizing the lamprey model, a detailed understanding of sensorimotor integration in vertebrates is emerging. In this article, we explore how the vertebrate CNS integrates sensory signals to generate motor behavior by examining the pathways and neural mechanisms involved in the transformation of cutaneous and olfactory inputs into motor output in the lamprey. We then review how 5-hydroxytryptamine (5-HT) acts on these systems by modulating both sensory inputs and motor output. A comprehensive review of this fundamental topic should provide a useful framework in the fields of motor control, sensorimotor integration and neuromodulation.

Keywords: sensorimotor, locomotion, modulation, reticulospinal neurons, lamprey, 5-HT

\section{INTRODUCTION}

Locomotion is a rhythmic motor behavior involved in everyday functions. It requires the activation and coordination of the axial and/or appendicular musculature. Spinal neuronal networks called "central pattern generators" (CPGs) for locomotion generate the patterns of muscle activation that underlie propulsion during locomotion. Supraspinal structures, on the other hand, are required

\footnotetext{
Abbreviations: 5-HT, 5-hydroxytryptamine; AMPA, $\alpha$-amino-3-hydroxy-5-methyl-4-isoxazolepropionic acid; AOO, accessory olfactory organ; ARRN, anterior rhombencephalic reticular nucleus; CPG, central pattern generator; DR, dorsal root; $\mathrm{dV}$, descending root of the trigeminal nerve; DCN, dorsal column nucleus; EPSC, excitatory post synaptic current; EPSP, excitatory post synaptic potential; MLR, mesencephalic locomotor region; MOE, main olfactory epithelium; MRN, mesencephalic reticular nucleus; MRRN, middle rhombencephalic reticular nucleus; ndV, nucleus of the descending root of the trigeminal nerve; NMDA, N-methyl-D-aspartate; NMDAR, N-methylD-aspartate receptor; OB, olfactory bulb; OLA, octavolateralis area; OSN, olfactory sensory neurons; PRRN, posterior rhombencephalic reticular nucleus; PT, posterior tuberculum; RS, reticulospinal; SC, spinal cord; SNAP-25, synaptosomal-associated protein 25 ; SNARE, soluble N-ethylmaleimide-sensitive factor attachment protein receptor; TTX, tetrodotoxin; VGCC, voltage-gated calcium channel; VR, ventral root.
} 
for activating and controlling the spinal CPGs. Descending inputs trigger, maintain, and eventually stop locomotion. The brainstem reticulospinal (RS) cells act as command cells that constitute an important interface between supraspinal and spinal networks. As such, the activation of RS cells by sensory (sensoryevoked locomotion) or internal clues (goal-directed locomotion) will markedly influence spinal function.

In this review, we focus on sensory-evoked locomotion by examining how two different sensory modalities influence the activation RS cells in a basal vertebrate, the lamprey. Because lampreys share a common brain "bauplan" with jawed vertebrates, including mammals, knowledge gained from neural circuits and mechanisms in lampreys provides insight into fundamental principles of vertebrate brain organization and function (Grillner et al., 1998b; Robertson et al., 2014). This review article focuses on some recent work in the lamprey from our labs on the pathways and neural mechanisms involved in the transformation of cutaneous and olfactory inputs into motor output. These sensory modalities are of paramount importance for the survival and reproductive success of individuals as they drive feeding, reproductive, and escape behaviors. We will also discuss 5-hydroxytryptamine (5-HT) modulation of these sensorimotor pathways. Indeed, 5-HT modulates both the sensory inputs to the RS cells at the supraspinal level and the descending motor commands of the RS cells in the spinal cord (SC). The mechanisms by which 5 -HT modulates synaptic transmission has been well described in lampreys (Takahashi et al., 2001; Alford et al., 2003; Gerachshenko et al., 2005; Schwartz et al., 2005; Photowala et al., 2006; Schwartz et al., 2007; Gerachshenko et al., 2009; Alpert and Alford, 2013).

After a brief review of the motor circuitry and neural mechanisms of locomotion, sensorimotor transformations will be addressed starting with the neural pathways, from the receptors to the neural centers, followed by the neural mechanisms. Sensorimotor transformations of cutaneous and olfactory inputs will be addressed similarly. We have recently shown that the neural connections for these two sensory modalities differ considerably, yet activate the same target cells in the lower brainstem, the RS cells (Viana Di Prisco et al., 2000; Derjean et al., 2010). The pathway for cutaneous-induced locomotor reactions is shorter and more direct to the RS cells than the pathway involved in olfactory-induced locomotion. The transformation mechanisms are also different. The RS cell responses to cutaneous inputs (mechanical stimulation) switch from subthreshold excitatory postsynaptic potentials (EPSPs) to large sustained depolarizations; the output being an all-ornone escape locomotor bout. The olfactory inputs likely provide a more finely controlled locomotor output by acting via the mesencephalic locomotor region (MLR), a specific brainstem region involved in controlling goal directed locomotion. This review article will compare these two sensorimotor systems at the levels of neuronal connectivity and cellular mechanisms. We will then examine how 5-HT acts on these systems. In the past we have shown that cutaneous sensory inputs to RS cells are modulated by 5-HT (Antri et al., 2008). Similarly, there is prominent 5 -HT innervation in the olfactory system, from the olfactory epithelium to the olfactory bulb (OB; Zielinski et al., 2000). Finally, we will review 5-HT modulation at the SC level. It has been extensively documented in the past that it exerts presynaptic effects that modulate the transmission from descending RS axons on SC neurons (Schwartz et al., 2005, 2007). This modulation has powerful effects on locomotor behavior.

\section{THE LAMPREY AS A VERTEBRATE MODEL OF SENSORIMOTOR INTEGRATION}

There is large interest in understanding the neural basis of behavior. The use of lampreys as a model system has made it possible to bridge the gap between cellular mechanisms and behavior. Indeed, the lamprey nervous system is remarkably similar to the mammalian nervous system, but it contains considerably fewer neurons and is thus greatly simpler. Moreover, lamprey brainstem command cells are more easily accessible for electrophysiological studies, which can be readily combined with imaging techniques in controlled in vitro conditions with the entire locomotor circuitry intact. The supraspinal mechanisms responsible for initiating and controlling locomotion can be studied with an array of in vitro techniques, with the added benefit of including all relevant structures needed for locomotor control, and the ability to monitor ongoing swimming behavior in a semi-intact preparation consisting of the exposed brain and rostral SC with the rest of the body left intact. As such, the lamprey model has paved the way for important discoveries, including the first detailed characterization of a vertebrate CPG for locomotion (Buchanan and Grillner, 1987). Acquisition of detailed knowledge of its motor circuitry opened the way for rapid progress in understanding sensorimotor integration at the system and cellular levels. For instance, new information on sensory-evoked locomotion was provided by describing the cellular mechanisms underlying the transformation of cutaneous inputs into locomotor output at the supraspinal level (Viana Di Prisco et al., 1997, 2000; Antri et al., 2009). For the first time in any vertebrate species, the neural substrate responsible for the transformation of olfactory inputs into a locomotor output was identified using the lamprey model (Derjean et al., 2010). Overall, the lamprey nervous system is ideally suited for the mechanistic study of sensorimotor integration.

\section{THE NEURAL CONTROL OF LOCOMOTION}

As indicated above, the basic muscle synergies responsible for locomotor propulsion are generated by SC networks collectively known as CPGs (reviewed in Grillner et al., 2008). CPGs are also involved in generating respiration (reviewed in Del Negro et al., 2002) and mastication (reviewed in Westberg and Kolta, 2011). The neuronal activity is produced by integrating the intrinsic properties of the CPG neurons and the synaptic connectivity of the inextricably linked neural network (Marder and Thirumalai, 2002; Alford et al., 2003). Synaptic activity, whether mediating the release of fast acting neurotransmitters such as glutamate or 
neuromodulators such as the monoamines, dopamine or 5-HT, modifies the intrinsic properties. The neural network of the lamprey locomotor CPG has been well characterized (Buchanan and Grillner, 1987). Ipsilateral glutamatergic excitation in conjunction with contralateral inhibition play a crucial role (Grillner and Wallén, 1980; Buchanan and Cohen, 1982; Brodin et al., 1985; Alford and Williams, 1989; Hellgren et al., 1992); They generate ventral root (VR) bursting that alternates across the SC (Grillner et al., 1995). The spinal locomotor circuit is activated by descending commands and in particular by glutamate release from brainstem RS cells (Buchanan et al., 1987; Ohta and Grillner, 1989). The intensity of input from RS axons regulates the frequency of these bursts of activity and therefore the speed of locomotion (Viana Di Prisco et al., 2000; Brocard and Dubuc, 2003), which may range from 0.1 to $10 \mathrm{~Hz}$. Experimentally, locomotor CPG activity in the SC may be activated by stimulating the lamprey brainstem in semi-intact preparations which generate RS output (McClellan and Grillner, 1984; Sirota et al., 2000; Brocard and Dubuc, 2003; Le Ray et al., 2003) or alternatively by applying glutamate receptor agonists in isolated SCs (Cohen and Wallén, 1980; Grillner et al., 1981). The alternating pattern of VR bursting recorded under these experimental conditions is referred to as "fictive locomotion", and drives the coordinated contraction of muscles necessary for lamprey swimming.

The principal neurotransmitter that activates spinal CPGs is glutamate. Work in lampreys (Grillner et al., 1981; Buchanan et al., 1987; Marder, 1994), Xenopus tadpoles (Dale and Roberts, 1984; Roberts and Alford, 1986; Marder and Thirumalai, 2002; Alford et al., 2003), newborn rats (Armstrong, 1986; Kudo and Yamada, 1987) and cats (Shik et al., 1966; Douglas et al., 1993; Sirota et al., 2000) demonstrates that $\alpha$-amino3-hydroxy-5-methyl-4-isoxazolepropionic acid (AMPA) and $\mathrm{N}$-methyl-D-aspartate (NMDA) receptor mediated transmission in the SC activates and maintains locomotion. These data are supported by direct recordings of EPSPs onto motoneurons and premotoneurons (Dale and Roberts, 1985; Brodin et al., 1988; Noga et al., 2003; Dubuc et al., 2008) and pharmacological manipulation of the resultant behaviors (Dale and Roberts, 1984; Brodin and Grillner, 1985; Cazalets et al., 1992; Chau et al., 2002; Rybak et al., 2006). Glutamatergic neurotransmission in the SC both directly excites neurons of the CPG, but may also activate either plateau properties of spinal cells as shown in the turtle (Hounsgaard and Kiehn, 1985; Guertin and Hounsgaard, 1998), or complex oscillatory properties in these neurons mediated by NMDA receptor voltage dependency and $\mathrm{Ca}^{2+}$ permeability. NMDA receptor-evoked neuronal oscillations were first shown in lamprey (Sigvardt et al., 1985; Wallén and Grillner, 1987), and were since identified in mammals (Hochman et al., 1994a,b; Wilson et al., 2005; Masino et al., 2012; for a review, see Schmidt et al., 1998).

The identity of the descending glutamatergic RS command neurons is well-defined in lampreys (Figure 1A; Dubuc et al., 2008). RS cells have been described anatomically and physiologically. They constitute about $90 \%$ of the neurones projecting to the SC (Swain et al., 1993; Bussières, 1994;
Davis and McClellan, 1994a,b). RS cells are located in one mesencephalic reticular nucleus (MRN) and three rhombencephalic reticular nuclei, the anterior (ARRN), the middle (MRRN) and the posterior (PRRN; Nieuwenhuys, 1972, 1977; Brodin et al., 1988; Swain et al., 1993; Davis and McClellan, 1994a,b). There are about 1250 RS cells on each side and about $85 \%$ of these are located in the PRRN and MRRN (Bussières, 1994). Numerous attempts to establish homologies of these nuclei to reticular nuclei in other vertebrate species have been made in the past (Kimmel et al., 1982; Cruce and Newman, 1984; ten Donkelaar et al., 1987; Nieuwenhuys and Nicholson, 1998; Brocard and Dubuc, 2003; Butler and Hodos, 2005; Nieuwenhuys, 2011). Based on the cytoarchitecture, anatomical position and connections of the reticular nuclei, the following homologies were proposed: (i) the ARRN and MRRN, which contain large medially-projecting RS cells (Müller cells; Rovainen, 1967), are homologous to the superior and middle reticular nuclei of fish, amphibians and reptiles. These nuclei would be respectively homologous to the nuclei pontis oralis and caudalis of mammals; (ii) the PRRN, which contains laterally-projecting RS cells, is homologous to the inferior reticular nuclei of fish, amphibians and reptiles. This nucleus is comparable to the nuclei reticularis gigantocellularis, ventralis and magnocellularis of mammals.

It has been shown in lampreys that the axons of large RS cells make synaptic contacts with several classes of spinal neurons and some are involved in generating locomotion (Rovainen, 1974; Buchanan, 1982; Ohta and Grillner, 1989; for a review of RS pathways in mammals, see Perreault and Glover, 2013). Similarly, studies conducted in mice and zebrafish showed that genetically identified glutamatergic RS cells of the hindbrain are involved in controlling locomotion (Hägglund et al., 2010; Bretzner and Brownstone, 2013; Kimura et al., 2013). Bouvier et al. (2015) recently identified a new population of RS cells involved in stopping locomotion. These studies opened the way to the genetic dissection of RS pathways, thus leading to further examination of their evolutionary conservation. As will be outlined below, locomotor activity is produced by spinal CPGs that are activated and maintained by descending commands. During goal-directed locomotion, this activity originates in forebrain structures, including the basal ganglia (Armstrong, 1986), to activate a largely serial process in which these higher centers recruit locomotor centers including the MLR (Shik et al., 1966; Eidelberg et al., 1981; Skinner and Garcia-Rill, 1984; Bernau et al., 1991; Marlinsky and Voitenko, 1991; Sirota et al., 2000; Cabelguen et al., 2003; Musienko et al., 2008; Ryczko et al., 2016; for reviews, see Le Ray et al., 2011; Ryczko and Dubuc, 2013) and then the RS system (Orlovskiǐ, 1970a,b, 1972; Shefchyk et al., 1984; Steeves and Jordan, 1984; Garcia-Rill et al., 1986; Jordan, 1986; Garcia-Rill and Skinner, 1987a,b). The MLR exerts an excitatory influence on RS cells either directly via glutamatergic and cholinergic (nicotinic) projections to the RS cells (Brocard and Dubuc, 2003; Le Ray et al., 2003; Noga et al., 2003; Grillner et al., 2008; Brocard et al., 2010) or indirectly via a cholinergic projection to glutamatergic muscarinoceptive cells of the brainstem that project back to 


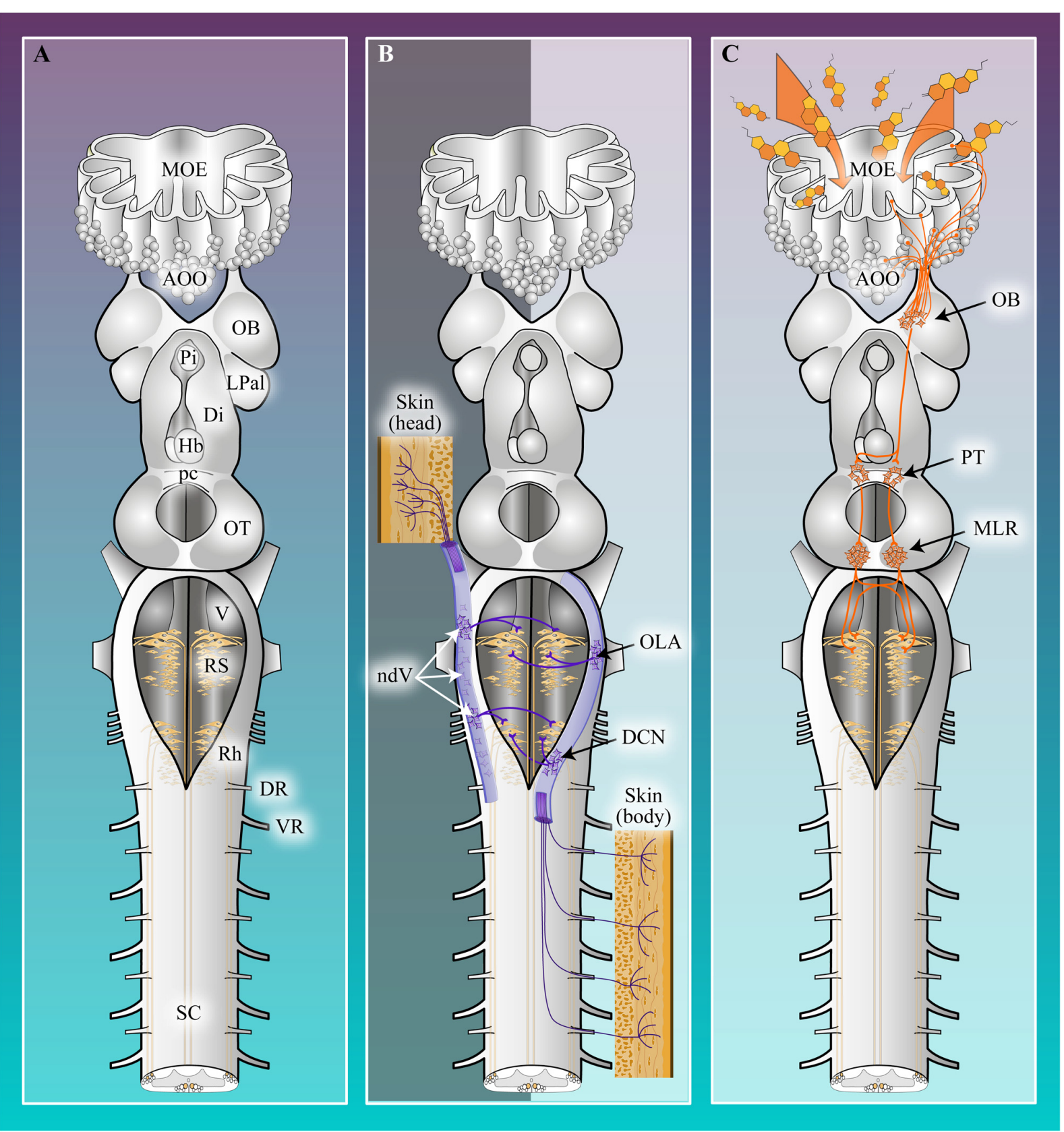

FIGURE 1 | Schematic representation of the brain and sensory-locomotor circuitry in lampreys. (A) The lamprey central nervous system (CNS). AOO, Accessory olfactory organ; Di, Diencephalon; DR, Dorsal root; Hb, Habenula; LPal, Lateral pallium; MOE, Main olfactory epithelium; OB, Olfactory bulb; OT, Optic tectum; pc, Posterior commissure; Pi, Pineal gland; Rh, Rhombencephalon; RS, Reticulospinal cells; SC, Spinal cord; V, Motor nucleus of the trigeminal nerve; VR, Ventral root. (B) The somato-locomotor pathway (purple) involves only a single relay, located in the alar plate, between the afferent sensory fibers and the RS cells. The inputs from the head region are relayed to RS cells by neurons located in the nucleus of the descending root of the trigeminal nerve (ndV), whereas inputs from the body are relayed to RS cells by neurons located in the dorsal column nucleus (DCN) or in the octavolateralis area (OLA). (C) The olfacto-locomotor pathway (orange) consists of a projection from the medial part of the OB to the mesencephalic locomotor region (MLR) via the posterior tuberculum (PT). The MLR controls locomotion in all vertebrate species through a direct projection to the command cells for locomotion, the RS cells (beige). The RS cells, in turn, project to the spinal central pattern generators (CPGs) that generate muscle synergies responsible for locomotion.

the RS cells (Smetana et al., 2007, 2010). The involvement of the cholinergic system in the control of locomotion is still subject to debate. Indeed, MLR cholinergic inputs have an excitatory influence on RS cells, but are not essential to induce locomotion (Brocard and Dubuc, 2003; Le Ray et al., 2003; Smetana et al., 2007, 2010; Jordan et al., 2014; Roseberry et al., 2016). As such, 
it seems that cholinergic inputs cooperate with glutamatergic inputs to amplify and sustain the locomotor output. Further investigations of the respective roles of the glutamatergic and cholinergic systems in the control of locomotion are needed.

\section{SENSORIMOTOR TRANSFORMATIONS OF CUTANEOUS INPUTS}

Cutaneous inputs can induce, modulate and stop locomotion in vertebrates (Duysens, 1977; Viala et al., 1978; Clarke and Roberts, 1984; McClellan and Grillner, 1984; Boothby and Roberts, 1992; Frigon et al., 2012; reviewed in Grillner, 1985; Rossignol et al., 2006). The anatomical pathways and cellular mechanisms underlying these sensorimotor transformations were first characterized in the lamprey (Dubuc et al., 1993a,b; Viana Di Prisco et al., 1997, 2000, 2005; Antri et al., 2009; Le Ray et al., 2010) and more recently in Xenopus (Buhl et al., 2012).

\section{The Neural Pathway: From Cutaneous Receptors to Brain Locomotor Centers}

As in other vertebrates, different types of mechanoreceptors are located on the skin of lampreys (Lethbridge and Potter, 1982). These include Merkel cells (Fahrenholz, 1936; Whitear and Lane, 1981), free nerve endings, and neuromasts (Lethbridge and Potter, 1982). Neuromasts are mechanosensory organs associated with the lateral line system and will not be discussed further here (see Gelman et al., 2007). The Merkel cells are present all over the body and are particularly abundant in the epidermis of the mouth, gills and fins (Fahrenholz, 1936; Whitear and Lane, 1981; Lethbridge and Potter, 1982). As seen in other vertebrates, these microvillar cells are connected to the surrounding epidermal cells by desmosomes and granules are concentrated at the site of apparent synaptic junctions with afferent nerve fibers. However, in the lamprey, their association with a nerve fiber is unique by the presence of a spur on the neurite (Whitear and Lane, 1981). Nerve fibers conveying cutaneous input enter the CNS by the dorsal roots (DRs) of the SC (body inputs) and by the trigeminal nerve (head inputs) (Figure 1B; Martin and Wickelgren, 1971; Matthews and Wickelgren, 1978; Rovainen and Yan, 1985; Christenson et al., 1988). Afferent fibers of the DRs and trigeminal nerve have their cell bodies within the brain/SC (dorsal cells) or in the DR ganglia/trigeminal ganglia (Rovainen and Yan, 1985). Most DR afferent fibers carrying somatosensory information from the body ascend, via the dorsal column, to terminate in the dorsal column nucleus (DCN) in the brainstem (Figure 1B; Dubuc et al., 1993b). Some fibers, however, continue further rostrally and reach the octavolateralis area (OLA; Figure 1B; Ronan and Northcutt, 1990; Dubuc et al., 1993b). Alar plate neurons from the DCN and OLA then project to the RS cells thus providing a disynaptic pathway for cutaneous inputs to reach the RS cells (Figure 1B; Dubuc et al., 1993b; Pflieger and Dubuc, 2004). Similarly, there is a disynaptic pathway relaying head somatosensory information to the RS cells (Figure 1B). After entering the brain by the sensory root of the trigeminal nerve, trigeminal afferent fibers form the descending root of the trigeminal nerve $(\mathrm{dV})$ that extends down to the rostral SC. There is no well-defined sensory nucleus of the descending root (ndV) in lampreys but neurons scattered among the $\mathrm{dV}$ fibers constitute a diffuse ndV (Northcutt, 1979; Viana Di Prisco et al., 2005). Interestingly, tract-tracing experiments showed that some of these neurons project to the RS cells and thus could constitute a trigeminal sensory relay to RS cells (Viana Di Prisco et al., 2005).

\section{The Neural Mechanisms}

Cutaneous primary sensory neurons (ganglion and dorsal cells) have been classified as touch, pressure, and possibly nociception, based on their response patterns to the skin stimulation. Touch cells are fast-adapting cells that respond to light mechanical stimulation of the skin with one or two spikes at the onset and offset of the stimulation (Martin and Wickelgren, 1971; Matthews and Wickelgren, 1978; Christenson et al., 1988). Pressure cells respond to mechanical stimulation of the skin by a slowly-adapting discharge with frequency related to the stimulus intensity. A third type of cell, the nociceptive cell, has been reported to respond to heavy pressure applied on the skin by a slowly-adapting discharge (Martin and Wickelgren, 1971; Matthews and Wickelgren, 1978; Rovainen and Yan, 1985). Activation of these primary sensory neurons by mechanical stimulation of the skin or electrical stimulation of the nerves (trigeminal or spinal DRs) induces post-synaptic potentials in intracellularly recorded RS cells (Viana Di Prisco et al., 1997, 2000, 2005). This finding is in accordance with behavioral observations showing that skin stimulation elicits escape swimming in intact animals (McClellan, 1988; Cardin et al., 1999). Excitatory and inhibitory amino acids are involved in the transmission of cutaneous inputs to RS cells (Dubuc et al., 1993a,b; Viana Di Prisco et al., 1995, 2005). The transmission from cutaneous (trigeminal and dorsal column) sensory afferent fibers to alar plate relay neurons was shown to be glutamatergic (Dubuc et al., 1993a,b; Viana Di Prisco et al., 1995, 2005). Cutaneous inputs are then relayed to RS cells by glycinergic and glutamatergic neurons of the relay nuclei (OLA and DCN for body inputs; $\mathrm{dV}$ for head inputs).

Further examination of the physiology of this disynaptic pathway led to a very interesting discovery on how RS cells transform a brief sensory input into a long-lasting motor output due to intrinsic plateau properties of RS cells (Viana Di Prisco et al., 1997). Indeed, the skin stimulation intensity-RS cell response intensity relationship is not strictly linear. At low intensities, skin stimulation elicits graded postsynaptic potentials in RS cells in a linear fashion. As the sensory stimulus intensity reaches a high level, the excitatory response in RS cells switches from sub-threshold to a large sustained depolarization that triggers escape locomotion in a semi-intact preparation. The sustaining depolarization is NMDA receptor-dependent and $\mathrm{Ca}^{2+}$ entry into the cell in turn activates a $\mathrm{Ca}^{2+}$-activated non-selective cation current $\left(\mathrm{I}_{\text {CAN }}\right)$. The sustained depolarizations often last for a very long duration (up to minutes). It was found that synaptic 
inputs could feed back onto intrinsic properties to temporally amplify the sustained depolarizations (Antri et al., 2009). Reversibly blocking SC inputs to RS cells markedly reduced the duration of the sustained depolarizations. In addition, pressure ejecting ionotropic glutamate receptor blockers on a recorded RS cell during the sustained depolarization reduced both their amplitude and duration. These findings indicate that excitatory synaptic inputs cooperate with intrinsic properties to prolong the sustained depolarizations (Antri et al., 2009). Whether similar mechanisms are involved in transforming sensory inputs from other sources into motor output remains to be determined.

\section{SENSORIMOTOR TRANSFORMATIONS OF OLFACTORY INPUTS}

Olfactory cues can induce locomotion in vertebrates (Hasler and Wisby, 1951; Fady et al., 1998; Varendi and Porter, 2001; Johnson et al., 2009; for a review, see Daghfous et al., 2012). However, the neural substrate underlying olfactory-activated locomotion has long eluded characterization. Pioneering work (Grimm, 1960; Døving and Selset, 1980) showed that electrical stimulation of the olfactory tracts in fishes induced stereotyped motor behaviors including locomotion. Moreover, recent investigations of neural circuits and cellular mechanisms in the sea lamprey have unraveled how olfactory inputs can initiate locomotion (Derjean et al., 2010).

\section{The Neural Pathway: From Olfactory Sensory Neurons to Brain Locomotor Centers}

In lampreys, a single nostril located along the midline on the dorsal surface of the head, anterior to the eyes opens into a single nasal cavity containing the peripheral olfactory organ. The walls of this cavity form folds or lamellae lined by an epithelium containing olfactory sensory neurons (OSNs). These lamellae house the main olfactory epithelium (MOE), and contain three ciliated OSN morphotypes: tall, intermediate and short OSNs (Laframboise et al., 2007). Their shapes and locations are similar to OSN morphotypes present in teleost fishes (Hansen and Zielinski, 2005). Diverticula (i.e., epithelial vesicles) of the MOE, mainly located in the caudoventral part of the olfactory organ, form the accessory olfactory organ (AOO) of lampreys (Scott, 1887; Leach, 1951; Hagelin and Johnels, 1955). The lumina of the AOO diverticula are linked to the lumen of the olfactory organ by tiny ducts (Hagelin and Johnels, 1955), and the cuboidal epithelium lining the AOO vesicles contains ciliated short OSNs with a broader surface than the short OSNs in the MOE (Ren et al., 2009; Chang et al., 2013). Axons extend from both MOE and AOO into the underlying lamina propria, where small axonal bundles gather to form the olfactory nerve. These OSN axons enter the $\mathrm{OB}$, the primary olfactory center of the brain, where synaptic contacts are made onto the second order olfactory neurons, the OB projection neurons (the equivalent of the "mitral/tufted" cells of mammals). Axons from AOO OSNs terminate only in the medial part of the OB whereas axons from MOE OSNs terminate in non-medial parts of the $\mathrm{OB}$ and possibly sparsely in the medial part of the OB (Ren et al., 2009). Interestingly, OSN axons extending into medial and non-medial regions of the $\mathrm{OB}$ have distinct biochemical properties (Frontini et al., 2003). Moreover, projection neurons located in the medial and non-medial part of $\mathrm{OB}$ have nonoverlapping receptive fields and exhibit differences in size and dendritic morphology (Green et al., 2013). The projection neurons send their projections to third order olfactory neurons in different parts of the brain. Structures receiving these secondary olfactory projections are located mainly in the telencephalon, but some secondary olfactory fibers extend to the mesodiencephalic boundary. Third order olfactory neurons are located in the septum, striatum, pallium, habenula, hypothalamus as well as the posterior tuberculum (PT), a ventrocaudal region of the diencephalon. Tract-tracing experiments revealed that the olfactory connection to the PT originates exclusively from the medial projection neuron population (Figure 1C), whereas connectivity to the other aforementioned areas arise from nonmedial projection neurons. Conversely, the PT appears to be the only target of the projection neurons of the medial $\mathrm{OB}$ (Figure 1C; Figure 5 in Derjean et al., 2010; Green et al., 2013). This OB projection to the PT is of special interest as it was previously shown that the PT sends downward inputs to the MLR (Figure 1C; Ménard et al., 2007). The MLR is a crucial motor center located at the border between the mesencephalon and the pons. In all vertebrate species, it controls locomotion in a graded fashion, via projections to RS cells (for reviews, see Dubuc et al., 2008; Ryczko and Dubuc, 2013). Thus, the projection from the medial OB to the PT provides a way for olfactory inputs to influence locomotion in a very direct fashion (Figure 1C).

\section{The Neural Mechanisms}

The activation of OSNs by chemical stimuli constitutes the first step of any olfactory-mediated behavior. In lampreys, OSNs have been shown to respond to three major classes of chemical stimuli: amino acids, steroids, and bile salts ( $\mathrm{Li}$ et al., 1995). Stimulation of the olfactory epithelium with some of these naturally occurring olfactory stimuli can induce sustained depolarizations with spiking activity in RS cells. The stimulatory molecules include the sex pheromones 3-keto petromyzonol sulfate and 3-keto allocholic acid as well as odors such as taurocholic acid and L-arginine (Figure 1 in Derjean et al., 2010). Similarly, electrical stimulation of the olfactory nerve elicits excitatory synaptic responses in intracellularly recorded RS cells (Wickelgren, 1977; Brodin et al., 1988; Figure 2 in Derjean et al., 2010). Responses occur on both sides with a latency of around $100 \mathrm{~ms}$. Calcium imaging experiments confirmed this finding by showing that repetitive stimulation of the olfactory nerve increases intracellular calcium in many RS cells (Figure 2 in Derjean et al., 2010), a sign of long-lasting afterdischarges in these cells (Viana Di Prisco et al., 1997). Local injections of glutamate antagonists in the $\mathrm{OB}$ blocked the responses of RS cells to olfactory nerve stimulation, indicating that synaptic transmission between OSNs and projection neurons 
relies on glutamate (Figure 2 in Derjean et al., 2010). The glutamatergic nature of this synapse was confirmed by showing that glutamate injection into the $\mathrm{OB}$ induces fictive locomotion (Figure 3 in Derjean et al., 2010). Examination of RS cell responses following the stimulation of different $\mathrm{OB}$ regions revealed that stimulating the medial region of the $\mathrm{OB}$ was more effective than stimulating non-medial regions (Figure 4 in Derjean et al., 2010). In summary, anatomical evidence and physiological experiments emphasise the role of the medial $\mathrm{OB}$ region in the fast relay of olfactory inputs to locomotor centers.

Because projection neurons from the medial OB region only project to the $\mathrm{PT}$, the effect of PT stimulation on RS cell activity was investigated. Electrical stimulation of the PT elicited excitatory responses in RS cells with a latency of around $15 \mathrm{~ms}$. Pharmacological stimulation of the PT with glutamate induced locomotor bouts in semi-intact preparations (Figure 6 in Derjean et al., 2010; Ryczko et al., 2013). Moreover, glutamate antagonist injections into the PT abolished RS cells responses to olfactory nerve stimulation, demonstrating that the $\mathrm{OB}$ projections to the PT are glutamatergic and that the PT is involved in olfactomotor transformations (Figure 7 in Derjean et al., 2010). Because the MLR receives inputs from the PT (Ménard et al., 2007) and projects to RS cells (Sirota et al., 2000), it is an ideal candidate to relay PT olfactory inputs to RS cells. Physiological data support this hypothesis. Local injections of glutamate antagonists into the MLR block RS cells responses to olfactory nerve stimulation (Figure 7 in Derjean et al., 2010). In addition to driving the MLR via a glutamatergic projection, the PT also modulates its activity through a dopaminergic projection. It was shown recently that stimulation of the PT induces a dopamine release in the MLR, which increases the locomotor output by a D1 receptormediated mechanism (Ryczko et al., 2013). This dopaminergic drive seems to build on the glutamatergic drive to amplify the overall PT input onto the MLR. It remains to be shown, however, whether PT dopaminergic neurons are actually recruited by olfactory inputs from medial $\mathrm{OB}$ projection neurons. In turn, the MLR activates RS cells (Brocard and Dubuc, 2003; Le Ray et al., 2003; Brocard et al., 2010). As such, the MLR plays a key central role in initiating and controlling locomotion (Sirota et al., 2000; Le Ray et al., 2011; Ryczko and Dubuc, 2013) induced by olfactory inputs and finely tunes the power of the locomotor output.

\section{COMPARISON OF THE TWO SENSORIMOTOR SYSTEMS}

The activation of locomotion by the two sensory modalities, cutaneous mechanoreception and olfaction, relies on the activation of RS cells in the brainstem. Cutaneous inputs activate RS cells through relay cells located in the lateral part of the hindbrain or in the dorsal column nuclei. Olfactory inputs activate RS cells through the MLR. It is well documented that the MLR activates RS cells in a graded fashion and this results in a graded locomotor output. On the other hand, cutaneous inputs generate sustained depolarizations in RS cells in an all-or-none fashion. The sustained depolarizations were recently shown to rely on intrinsic properties ( $\mathrm{I}_{\mathrm{CAN}}$ ) as well as glutamatergic synaptic transmission (Viana Di Prisco et al., 2000). $\mathrm{Ca}^{2+}$ imaging experiments indicate that the large RS cells are activated by both olfactory and cutaneous inputs (Viana Di Prisco et al., 1997, 2000; Derjean et al., 2010), indicating that these RS cells play a crucial role in activating locomotion induced by either sensory modality. The mechanism by which the same RS cell population could elicit graded vs. all-or-none locomotor responses have not been elucidated. It is tempting to propose that intrinsic plateau properties could be inhibited by the MLR, which is known to excite RS cells via two neurotransmitters, glutamate and acetylcholine (Le Ray et al., 2003). For instance, cholinergic inputs could suppress NMDA-induced sustained depolarizations in RS cells. There are many other possible mechanisms. The level of excitation from the MLR could be insufficient to activate the intrinsic plateau properties in RS cells, as shown in the cat preparation for sensory inputs (Brownstone et al., 1994). Another possibility would be that the intrinsic plateau properties are activated by an unidentified synaptic input originating from the cutaneous sensory inputs and not the MLR. Further work is needed to decipher between these different options.

\section{5-HT MODULATION}

The general organization of the serotoninergic system in lampreys is relatively well described (Pierre et al., 1992; Antri et al., 2006; Barreiro-Iglesias et al., 2009) and it is similar to that of mammals. 5-HT modulates sensory transmission at different levels in the nervous system (Figure 2, left). For instance, several studies have shown that 5-HT modulates sensory transmission in the SC. In mammals, sensory transmission to superficial and deep dorsal horn neurons is either depressed by 5-HT (cat: Headley et al., 1978; Anwyl, 1990; and rat: Lopez-Garcia and King, 1996; Lopez-Garcia, 1998; Garraway and Hochman, 2001) or, in a small proportion of cases, potentiated by 5-HT (rat: ElYassir et al., 1988; Lopez-Garcia and King, 1996). In tadpoles (Sillar and Simmers, 1994) and lampreys, 5-HT decreases the amplitude of EPSPs recorded in large secondary sensory neurons (giant interneurons) in response to stimulation of primary afferents (El Manira et al., 1997). In frog motoneurons, 5-HT also depresses the EPSPs induced by DR stimulation (Ovsepian and Vesselkin, 2006). Less is known about 5-HT effects on sensory transmission at the supraspinal level. A study in guinea pigs suggested that 5 -HT depresses glutamate release from trigeminal primary afferents through presynaptic inhibition (Travagli and Williams, 1996). In the lamprey, 5-HT modulation occurs at several locations along the sensorimotor pathways.

\section{Serotoninergic Modulation of Cutaneous Inputs}

Modulatory effects of 5-HT were also investigated on the transmission of sensory inputs in the brainstem of lampreys 


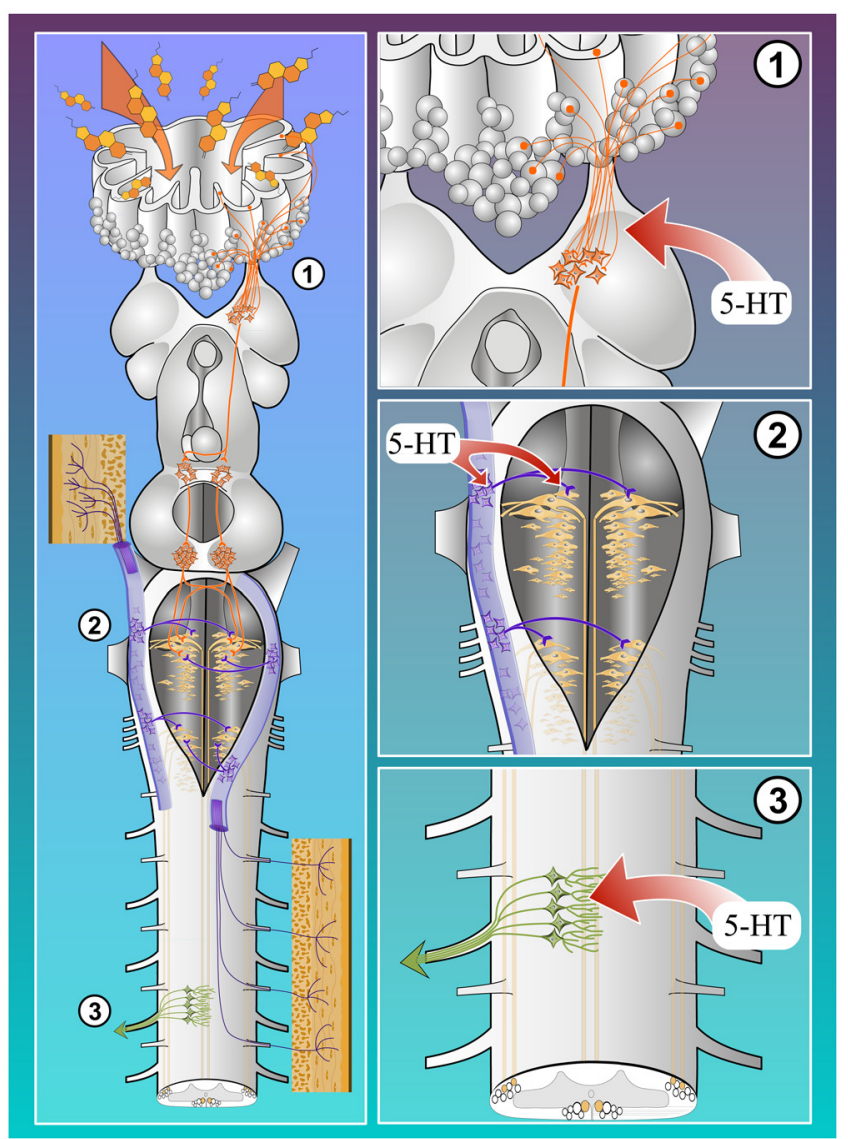

FIGURE 2 | 5-HT modulation of the sensorimotor circuitry. Both olfactory (1) and cutaneous (2) inputs to lamprey RS cells seem to be modulated by 5-HT (red arrows). 5-HT also acts at the spinal level by modulating the transmission from descending RS axons on spinal neurons (3).

(Figure 2-2). The lamprey brainstem contains rich 5-HT innervation (Steinbusch et al., 1981). There are 5-HT fibers surrounding the cell bodies of some of the large RS cells (Viana Di Prisco et al., 1994). Moreover, there is abundant 5-HT innervation within the trigeminal descending tract (Pierre et al., 1992), where the trigeminal sensory relay cells are located (Viana Di Prisco et al., 2005). 5-HT modulation of trigeminal inputs to RS cells was investigated in the brainstem of lampreys (Antri et al., 2008). Bath application of 5-HT reduced disynaptic excitatory responses in RS cells elicited by trigeminal nerve stimulation. Similar effects were seen by local ejection of 5-HT either onto the RS cells or onto the relay cells in the lateral part of the brainstem (Figure 2-2). 5-HT also reduced the monosynaptic EPSPs elicited from stimulation of the relay cells that receive trigeminal inputs and project onto RS cells. 5-HT increased the threshold for eliciting sustained depolarizations in response to trigeminal nerve stimulation but did not prevent them. The 5-HT innervation on RS cells appeared to originate from 5-HT neurons in the isthmic region, and also from neurons located in the pretectum and caudal rhombencephalon (Figure 2-2). These results indicate that 5 -HT strongly modulates sensory transmission to neural networks involved in the control of movements.

\section{Serotoninergic Modulation of Olfactory Inputs}

In the lamprey olfactory system, 5-HT fibers were particularly prominent in the lamina propria of the olfactory epithelium, as well as in the olfactory nerve and bulb (Figure 2-1; Zielinski et al., 2000; Frontini et al., 2003; Abalo et al., 2007). On the other hand, 5-HT cell bodies were restricted to the lamina propria underlying the olfactory epithelium (Figures 1-3 in Zielinski et al., 2000). The 5-HT fibers were prominent within the olfactory nerve, parallel to the axons of the OSNs, from the lamina propria to the OB. However, some 5-HT fibers were also seen adjacent to the olfactory nerve. Cross sections of the olfactory nerve revealed that the 5-HT fibers where distributed evenly among the primary olfactory afferent fibers forming the nerve. Analysis of the pathway of individual 5-HT fibers using confocal $\mathrm{z}$-series showed that these fibers terminated either at the junction of the olfactory nerve and $\mathrm{OB}$ or in the outer $\mathrm{OB}$ layers (i.e., olfactory nerve layer and glomerular layer). Olfactory nerve lesions experiments showed that these 5-HT fibers originate from cell bodies located in the mucosa of the olfactory organ (Zielinski et al., 2000). On the other hand, the abundant 5-HT innervation observed in the $\mathrm{OB}$ inner layers (i.e., granular) was not altered after cutting the olfactory nerve, demonstrating that this innervation has a different, probably central, origin. In lampreys, 5-HT neurons are present from the diencephalon to the caudal rhombencephalon (Antri et al., 2006). The telencephalon is devoid of serotonergic cell bodies (Pierre et al., 1992). Most afferents to the OB come from the telencephalon. However, some neurons projecting to the $\mathrm{OB}$ are located in the diencephalon (preoptic area) and midbrain tegmentum (Northcutt and Puzdrowski, 1988). Both these regions contain 5-HT neurons (Pierre et al., 1992; Antri et al., 2006), making them prime candidates as the central source of the OB 5-HT innervation. Interestingly, the meso-rhombencephalic group of 5-HT neurons seems to be homologous to the superior raphe of mammals (Antri et al., 2006), which is known to project to the $\mathrm{OB}$ and gate the olfactory information flow (Petzold et al., 2009). The function of the 5-HT innervation of the lamprey olfactory system is not fully understood (Zielinski et al., 2000). However, based on ongoing work in our group (Boyes et al., 2014), on the location of the 5-HT fibers in the OB (Zielinski et al., 2000), on how 5-HT acts on other sensory systems (Antri et al., 2008), and on the role of 5-HT in olfactory processing in other vertebrates (Petzold et al., 2009), it probably acts on olfactory processes by gating the sensory inflow.

\section{Serotoninergic Modulation of the Spinal Motor System}

Several endogenous neurotransmitters have been shown to alter the output of locomotor CPGs and to modulate cellular and synaptic properties of the neurons involved (see for 
instance: Barbeau and Rossignol, 1991; Schotland et al., 1996; MacLean et al., 1998; Parker and Grillner, 2000; Schmidt and Jordan, 2000; MacLean and Schmidt, 2001; Grillner and Wallén, 2002; Alford et al., 2003; Perrier et al., 2003; Svensson et al., 2003). Little is known about the mechanisms involved. However, the subject is broad and we will not review the different neurotransmitter systems in different vertebrate species.

In lampreys, 5-HT modulates the descending motor commands in the lamprey SC in addition to gating sensory inputs to RS cells. Paracrine release of 5-HT activates at least two distinct receptor subtypes at three distinct subcellular locations with transduction mechanisms converging on a single behavioral modification. It has been observed a while ago that the frequency of fictive locomotion is modulated by endogenous release of neurotransmitters within the SC (Harris-Warrick and Cohen, 1985; Christenson et al., 1989; Schotland et al., 1996; Parker and Grillner, 2000; Svensson et al., 2003). Of these modulatory neurotransmitters, 5-HT reduces the frequency of VR bursting during fictive locomotion (Harris-Warrick and Cohen, 1985). This modulation occurs if 5-HT is applied exogenously, but it is also clear that activitydependent release of 5-HT from within the SC occurs and that this release similarly reduces the frequency of the $\mathrm{CPG}$ output (Christenson et al., 1989). This behavioral outcome of 5-HT is due, in part, to 5-HT-mediated inhibition of a postsynaptic $\mathrm{Ca}^{2+}$-dependant $\mathrm{K}^{+}$-current $(\mathrm{KCa} 2)$ that underlies the late after-hyperpolorization of action potentials in neurons of the CPG (Wallén et al., 1989a; El Manira et al., 1994; Wikström et al., 1995; Parker and Grillner, 2000). Separately and associated directly with the synaptic activation of NMDA receptors, 5-HT mediated inhibition of a postsynaptic $\mathrm{KCa} 2$ is thought to play a role in prolonging fictive locomotion bursts through prolonging the plateau of NMDA tetrodotoxin (TTX) oscillations (Wallén and Grillner, 1987; Christenson et al., 1989; Wallén et al., 1989b; Schotland and Grillner, 1993; El Manira et al., 1994; Alpert and Alford, 2013; Nanou et al., 2013). Finally, presynaptic 5-HT receptor activation filters synaptic output from both descending RS command neurons (Buchanan and Grillner, 1991; Blackmer et al., 2001) and from intraspinal excitatory interneurons (Parker and Grillner, 1999; Schwartz et al., 2005). This form of presynaptic inhibition causes an augmenting synaptic response that is initially inhibited but enhanced during bursting behavior.

\section{Serotonin Modulation of $\mathrm{Ca}^{2+}$ Dependent $\mathrm{K}^{+}$ Conductances (KCa2) in Spinal Neurons}

5 -HT acts on most if not all neurons of the spinal CPG to inhibit the latter after hyperpolarization following action potentials (Wallén et al., 1989a). This effect may be mediated by 5 -HT1A receptors to inhibit voltage gated $\mathrm{Ca}^{2+}$ channels (Hill et al., 2003). The consequent reduction in $\mathrm{Ca}^{2+}$ will inhibit the $\mathrm{KCa} 2$ channel activation that mediates the late afterhyperpolarization in these neurons (Wikström and El Manira, 1998). The late after-hyperpolarization strongly impacts the ability of spinal neurons to fire repetitively during bursting activity that some neurons of the CPG show and thus, 5-HT modulation of $\mathrm{KCa} 2$ channels is important in controlling the burst output of the CPG (Wallén et al., 1989a; Hill et al., 1992; Meer and Buchanan, 1992). Indeed, computer simulations of the lamprey CPG network that incorporate its connectivity and ionic intrinsic properties provide evidence that inhibition of $\mathrm{KCa} 2$ in neurons within the lamprey $\mathrm{CPG}$ prolongs fictive locomotion VR bursting (Hellgren et al., 1992; Lansner and Ekeberg, 1994; Grillner et al., 1998a). 5-HT also causes a prolongation of the depolarization recorded during NMDATTX driven intrinsic oscillations (Wallén et al., 1989a). These oscillations are mediated by intrinsic membrane properties of spinal neurons seen following NMDA receptor activation. The oscillations require $\mathrm{Ca}^{2+}$ permeation of the NMDA receptors and subsequent activation of a KCa2 channel. The prolongation of the depolarizing phase of these oscillations caused by 5 -HT may be mediated by direct interaction of 5-HT receptors on $\mathrm{KCa} 2$ channels, or alternatively, via an indirect inhibition of N-methyl-D-aspartate receptors (NMDARs; Schotland and Grillner, 1993) or voltage-gated calcium channels (VGCCs; Wang et al., 2014) supplying $\mathrm{Ca}^{2+}$ for $\mathrm{KCa} 2$ channels responsible for the repolarization. More recent work ties the activation of NMDA receptors and $\mathrm{Ca}^{2+}$ permeation of these receptors directly to the activation of $\mathrm{KCa} 2$ channels, which are held in very close proximity (Alpert and Alford, 2013; Nanou et al., 2013). There is evidence that the effect of 5-HT on the NMDA mediated TTX resistant oscillations is also very important for the modulatory effects of 5-HT on the locomotor pattern. The effects of 5-HT are absent when the network is activated by kainate, which will not activate NMDARs directly. Thus, NMDAR-dependent $\mathrm{Ca}^{2+}$ entry contributes to burst termination (Alpert and Alford, 2013; Nanou et al., 2013). This effect is mediated by $\mathrm{KCa} 2$ activation, which is modified by 5 -HT. These effects of 5-HT mediated through $\mathrm{KCa} 2$ have been shown principally in the isolated SC during fictive locomotion activated by the artificial application of NMDA. However, the effects can be readily reproduced in the SC following brainstem activation of fictive locomotion (Figure 3; Gerachshenko et al., 2009; Nanou et al., 2013).

\section{Serotonin Modulates Glutamate Release in the Spinal Cord}

In addition to activating a postsynaptic $\mathrm{IK}(\mathrm{Ca})$, 5-HT presynaptically inhibits synaptic transmission in the lamprey SC (Figure 2-3; Buchanan and Grillner, 1991; El Manira et al., 1994; Shupliakov et al., 1995; Blackmer et al., 2001; Takahashi et al., 2001). The inhibition of synaptic transmission by $5-\mathrm{HT}$ has been observed in the CPGs of several jawed vertebrate as well. 5-HT presynaptically inhibits midcycle glycinergic inputs and prolongs VR bursting during Xenopus larval swimming (Sillar et al., 1998). In neonatal rat, activation of 5-HT receptors presynaptically decreases inspiratory modulated synaptic currents (Lindsay and Feldman, 1993; Di Pasquale et al., 1997; Hilaire et al., 1997) and suppresses descending glutamatergic responses (Skagerberg and Björklund, 1985). In mammalian locomotor descending command systems, 


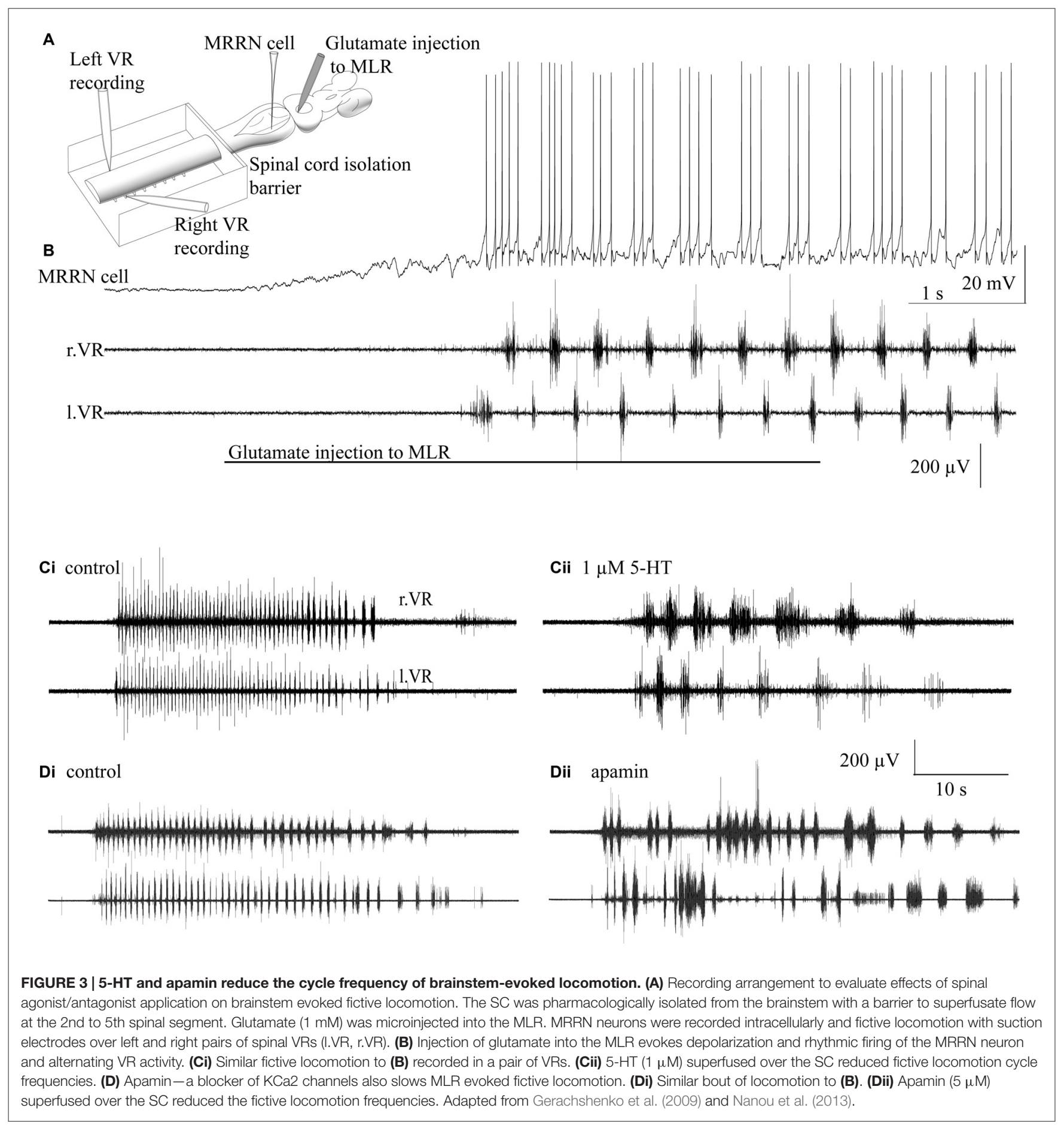

5-HT is a critical neurotransmitter. Bath applied 5-HT activates spinal rhythmic activity in rats (Cazalets et al., 1992) and refines locomotor-like activity (Pearlstein et al., 2005). 5-HT acting at 5-HT2A and 5-HT7 receptors to mediate excitatory effects (Liu and Jordan, 2005; Sławińska et al., 2014). However, 5-HT can also mediate inhibitory effects on spinal locomotor circuitry. Within descending locomotor command systems serotonin inhibits locomotor activity acting through either 5-HT1A or 5-HT1B/D receptor subtypes (Beato and Nistri, 1998; Dunbar et al., 2010), though the cellular and molecular sites of action remain unexplored. In the lamprey, the effect of presynaptic modulation of glutamatergic transmission converges on the same behavioral outcome (shown in Figure 3). This is true whether the CPG is activated by brainstem stimulation (Gerachshenko et al., 2009) or by bath application of glutamatergic agonists to 
the SC (Schwartz et al., 2005). The mechanism by which presynaptic 5-HT receptors mediate presynaptic modulation provides an explanation of how this convergence can occur.

In lamprey RS axons, 5-HT acting at a 5-HT1B receptor (Schwartz et al., 2005) liberates presynaptic G $\beta \gamma$ from the $\mathrm{G}$ protein heterodimer, to compete with $\mathrm{Ca}^{2+}$-dependent binding of the $\mathrm{Ca}^{2+}$ sensor for synaptic vesicle fusion, synaptotagmin, to the machinery for synaptic vesicle fusion-the soluble N-ethylmaleimide-sensitive factor attachment protein receptor (SNARE) complex (Blackmer et al., 2001, 2005; Takahashi et al., 2001; Gerachshenko et al., 2005, 2009). This competition is mediated principally by a small number of synaptosomal-associated protein 25 (SNAP-25) residues (Wells et al., 2012). Rather than causing a reduction in the probability of release at these synapses, this competitive interaction between $G \beta \gamma$ and synaptotagmin reduces synaptic cleft glutamate concentrations (Schwartz et al., 2007), by causing kiss-and-run fusion of the synaptic vesicles (Photowala et al., 2006). Lower synaptic glutamate concentrations cause AMPA receptor excitatory post synaptic currents (EPSCs) to be more profoundly inhibited than NMDA receptor EPSCs (Schwartz et al., 2007). Thus, 5-HT causes a differential inhibition with much stronger inhibition of AMPA mediated EPSCs. This effect is seen both at RS synapses and in synapses from intraspinal excitatory interneurons (Schwartz et al., 2005; Gerachshenko et al., 2009). Interestingly, fictive locomotion mediated by NMDA receptor activation is much slower than that mediated by AMPA or kainate application (Brodin et al., 1985; Brodin and Grillner, 1986). This is one means by which presynaptic 5-HT receptors slow fictive locomotion. However, the effect of G $\beta \gamma$ on modulating neurotransmitter release is dependent upon its competition with synaptotagmin in binding to the SNARE complex. Synaptotagmin binding to the SNARE complex is $\mathrm{Ca}^{2+}$-dependent. Consequently, at high $\mathrm{Ca}^{2+}$ concentrations, preferential synaptotagmin binding to SNARE complexes occludes 5-HT receptor-mediated inhibition (Yoon et al., 2007) by displacing G $\beta \gamma$ from the SNARE complex. During bursting activity, $\mathrm{Ca}^{2+}$ concentrations in the presynaptic terminals summate. This rising $\mathrm{Ca}^{2+}$ concentration inactivates 5 -HT mediated presynaptic inhibition within 3-5 action potentials of a $50 \mathrm{~Hz}$ burst (Gerachshenko et al., 2009). Computational simulations of the spinal circuitry for locomotion reveal that such an augmenting excitatory synaptic signal within the spinal CPG mediates a slower fictive locomotor activity (Hellgren et al., 1992; Parker and Grillner, 1999). In mammalian systems, the cellular mechanisms of action of 5-HT are less well understood, but a similarly complex series of effects has been associated with excitatory 5-HT2 and 5-HT7 receptors and inhibitory 5-HT1 receptors. Thus, 5-HT release within the mammalian SC both facilitates locomotion but also modulates rhythmic activity (Perrier and Cotel, 2015).

\section{Summary of the Effects of 5-HT on the Spinal CPG} 5-HT can be released within the SC (Figure 2-3), and its release causes a slowing of fictive locomotion, whether activated by exogenous agonists, or by brainstem stimulation. However, at least three functionally distinct receptors mediate effects that converge on this behavioral outcome. Two postsynaptic receptors cause a reduction in the activation of a $\mathrm{KCa} 2$ channel. One of these inhibits the action potential late afterhyperpolarization to sustain spiking during bursts, the other prevents burst termination by inhibiting an NMDA receptor dependent activation of a KCa2. Presynaptically, 5-HT1B receptors inhibit release by causing kiss and run fusion. This effect favors activation of postsynaptic NMDA receptors over AMPA, but also the inhibition is lost during bursts. Both of these presynaptic effects contribute to a slowing of the CPG frequency. Further studies are needed to establish whether similar mechanisms act at the sensory level and how 5-HT modulation in the SC impacts sensory-evoked locomotion.

\section{GENERAL CONCLUSIONS}

Sensory inputs from different modalities induce locomotion. Studies in lampreys have been extremely useful for gaining an understanding of the function and the regulation of these mechanisms. Both cutaneous and olfactory inputs impinge on RS cells that constitute the final common descending pathway for eliciting locomotion. Yet, the mechanisms by which RS cells are activated differ according to the sensory modality. Future research should indicate more precisely how graded vs. all-or-none locomotor output is elicited by olfactory vs. cutaneous inputs. Moreover, modulatory mechanisms also play a crucial role in gating the sensory inflow and determining the strength of the locomotor output. For instance, we have discussed how 5-HT acts at all levels of the sensorimotor pathways via different modulatory mechanisms.

\section{AUTHOR CONTRIBUTIONS}

GD, WWG, STA, BSZ, and RD wrote the article.

\section{FUNDING}

We acknowledge the support of the Great Lakes Fishery Commission over the years, as group grants to BZ and RD (GLFC, 54011, 54021, 54035). Group Grants provide the necessary conditions to promote in-depth reviews of this kind. This work was also supported by a grant to RD from the Natural Sciences and Engineering Research Council of Canada (NSERC, 217435), a grant from the Canadian Institutes of Health Research (CIHR, 15129) and a group grant from the Fonds de Recherche du Québec - Santé (FRQS, 5249).

\section{ACKNOWLEDGMENTS}

We would like to thank D. Veilleux, F. Bernard, S. Baker, and C. Valiquette for their technical assistance, as well as F. Auclair for his useful comments on the manuscript. 


\section{REFERENCES}

Abalo, X. M., Villar-Ceda, B., Meléndez-Ferro, M., Pérez-Costas, E., Anadón, R., and Rodicio, M. C. (2007). Development of the serotonergic system in the central nervous system of the see lamprey. J. Chem. Neuroanat. 34, 29-46. doi: 10.1016/j.jchemneu.2007.03.010

Alford, S., Schwartz, E., and Viana di Prisco, G. (2003). The pharmacology of vertebrate spinal central pattern generators. Neuroscientist 9, 217-228. doi: 10 . 1177/1073858403009003014

Alford, S., and Williams, T. L. (1989). Endogenous activation of glycine and NMDA receptors in lamprey spinal cord during fictive locomotion. J. Neurosci. 9, 2792-2800.

Alpert, M. H., and Alford, S. (2013). Synaptic NMDA receptor-dependent Ca(2+) entry drives membrane potential and $\mathrm{Ca}(2+)$ oscillations in spinal ventral horn neurons. PLoS One 8:e63154. doi: 10.1371/journal.pone.0063154

Antri, M., Auclair, F., Albretch, J., Djeudjang, S., and Dubuc, R. (2008). Serotoninergic modulation of sensory transmission to brainstem reticulospinla cells. Eur. J. Neurosci. 28, 655-667. doi: 10.1111/j.1460-9568.2008. 06368.x

Antri, M., Cyr, A., Auclair, F., and Dubuc, R. (2006). Ontogeny of 5-HT neurons in the brainstem of the lamprey, Petromyzon marinus. J. Comp. Neurol. 495, 788-800. doi: 10.1002/cne.20910

Antri, M., Fénelon, K., and Dubuc, R. (2009). The contribution of synaptic inputs to sustained depolarizations in reticulospinal neurons. J. Neurosci. 29, 1140-1151. doi: 10.1523/JNEUROSCI.3073-08.2009

Anwyl, R. (1990). Neurophysiological actions of 5-hydroxytryptamine in the vertebrate nervous system. Prog. Neurobiol. 35, 451-468. doi: 10.1016/03010082(90)90031-b

Armstrong, D. M. (1986). Supraspinal contributions to the initiation and control of locomotion in the cat. Prog. Neurobiol. 26, 273-361. doi: 10.1016/03010082(86)90021-3

Barbeau, H., and Rossignol, S. (1991). Initiation and modulation of the locomotor pattern in the adult chronic spinal cat by noradrenergic, serotonergic and dopaminergic drugs. Brain Res. 546, 250-260. doi: 10.1016/00068993(91)91489-n

Barreiro-Iglesias, A., Aldegunde, M., Anadón, R., and Rodicio, M. C. (2009). Extensive presence of serotonergic cells and fibers in the peripheral nervous system of lampreys. J. Comp. Neurol. 512, 478-499. doi: 10.1002/cne. 21914

Beato, M., and Nistri, A. (1998). Serotonin-induced inhibition of locomotor rhythm of the rat isolated spinal cord is mediated by the 5-HT1 receptor class. Proc. Biol. Sci. 265, 2073-2080. doi: 10.1098/rspb.1998.0542

Bernau, N. A., Puzdrowski, R. L., and Leonard, R. B. (1991). Identification of the midbrain locomotor region and its relation to descending locomotor pathways in the Atlantic stingray, Dasyatis sabina. Brain Res. 557, 83-94. doi: 10. 1016/0006-8993(91)90119-g

Blackmer, T., Larsen, E. C., Bartleson, C., Kowalchyk, J. A., Yoon, E.-J., Preininger, A. M., et al. (2005). G protein $\beta \gamma$ directly regulates SNARE protein fusion machinery for secretory granule exocytosis. Nat. Neurosci. 8, 421-425. doi: 10. 1038/nn1423

Blackmer, T., Larsen, E. C., Takahashi, M., Martin, T. F., Alford, S., and Hamm, H. E. (2001). G protein betagamma subunit-mediated presynaptic inhibition: regulation of exocytotic fusion downstream of $\mathrm{Ca}^{2+}$ entry. Science 292, 293-297. doi: 10.1126/science.1058803

Boothby, K. M., and Roberts, A. (1992). The stopping response of Xenopus laevis embryos: behaviour, development and physiology. J. Comp. Physiol. A 170, 171-180. doi: 10.1007/bf00196899

Bouvier, J., Caggiano, V., Leiras, R., Caldeira, V., Bellardita, C., Balueva, K., et al. (2015). Descending command neurons in the brainstem that halt locomotion. Cell 163, 1191-1203. doi: 10.1016/j.cell.2015.10.074

Boyes, K., Green, W. W., Aurangzeb, Z., Dubuc, R., and Zielinski, B. (2014). "Serotonergic modulation of odour-evoked neural activity in the olfactory bulb of the sea lamprey (Petromyzon marinus)," in Electronic Theses and Dissertations, Paper 5062, Department of Biological Sciences, University of Windsor: Windsor, $\mathrm{ON}$.

Bretzner, F., and Brownstone, R. M. (2013). Lhx3-Chx10 reticulospinal neurons in locomotor circuits. J. Neurosci. 33, 14681-14692. doi: 10.1523/JNEUROSCI. 5231-12.2013
Brocard, F., and Dubuc, R. (2003). Differential contribution of reticulospinal cells to the control of locomotion induced by the mesencephalic locomotor region. J. Neurophysiol. 90, 1714-1727. doi: 10.1152/jn.00202.2003

Brocard, F., Ryczko, D., Fénelon, K., Hatem, R., Gonzales, D., Auclair, F., et al. (2010). The transformation of a unilateral locomotor command into a symmetrical bilateral activation in the brainstem. J. Neurosci. 30, 523-533. doi: 10.1523/JNEUROSCI.3433-09.2010

Brodin, L., and Grillner, S. (1985). The role of putative excitatory amino acid neurotransmitters in the initiation of locomotion in the lamprey spinal cord. I. The effects of excitatory amino acid antagonists. Brain Res. 360, 139-148. doi: 10.1016/0006-8993(85)91229-6

Brodin, L., and Grillner, S. (1986). Effects of magnesium on fictive locomotion induced by activation of N-methyl-D-aspartate (NMDA) receptors in the lamprey spinal cord in vitro. Brain Res. 380, 244-252. doi: 10.1016/00068993(86)90219-2

Brodin, L., Grillner, S., Dubuc, R., Ohta, Y., Kasicki, S., and Hökfelt, T. (1988). Reticulospinal neurons in lamprey: transmitters, synaptic interactions and their role during locomotion. Arch. Ital. Biol. 126, 317-345.

Brodin, L., Grillner, S., and Rovainen, C. M. (1985). N-Methyl-D-aspartate (NMDA), kainate and quisqualate receptors and the generation of fictive locomotion in the lamprey spinal cord. Brain Res. 325, 302-306. doi: 10 1016/0006-8993(85)90328-2

Brownstone, R. M., Gossard, J. P., and Hultborn, H. (1994). Voltage-dependent excitation of motoneurones from spinal locomotor centres in the cat. Exp. Brain Res. 102, 34-44. doi: 10.1007/bf00232436

Buchanan, J. T. (1982). Identification of interneurons with colateral, caudal axons in the lamprey spinal cord: synaptic interactions and morphology. J. Neurophysiol. 47, 961-975.

Buchanan, J. T., Brodin, L., Dale, N., and Grillner, S. (1987). Reticulospinal neurones activate excitatory amino acid receptors. Brain Res. 408, 321-325. doi: 10.1016/0006-8993(87)90397-0

Buchanan, J. T., and Cohen, A. H. (1982). Activities of identified interneurons, motoneurons and muscle fibers during fictive swimming in the lamprey and effects of reticulospinal and dorsal cell stimulation. J. Neurophysiol. 47, 948-960.

Buchanan, J. T., and Grillner, S. (1987). Newly identified 'glutamate interneurons' and their role in locomotion in the lamprey spinal cord. Science 236, 312-314. doi: $10.1126 /$ science. 3563512

Buchanan, J. T., and Grillner, S. (1991). 5-hydroxytryptamine depresses reticulospinal excitatory post synaptic potentials in motoneurons of the lamprey. Neurosci. Lett. 122, 71-74. doi: 10.1016/0304-3940(91) 90196-z

Buhl, E., Roberts, A., and Soffe, S. R. (2012). The role of a trigeminal sensory nucleus in the initiation of locomotion. J. Physiol. 590, 2453-2469. doi: 10. 1113/jphysiol.2012.227934

Bussières, N. (1994). Les Systèmes Descendants Chez la Lamproie. Étude Anatomique et Fonctionnelle. Ph.D. thesis, Université de Montréal: Montréal, QC

Butler, A. B., and Hodos, W. (2005). "The reticular formation," in Comparative Vertebrate Neuroanatomy, 2nd Edn. eds A. B. Butler and W. Hodos (New York: Wiley-Liss), 164-179.

Cabelguen, J. M., Bourcier-Lucas, C., and Dubuc, R. (2003). Bimodal locomotion elicited by electrical stimulation of the midbrain in the salamander Notophthalmus viridescens. J. Neurosci. 23, 2434-2439.

Cardin, S., Le Ray, D., Robitaille, R., and Dubuc, R. (1999). Motor responses elicited by skin stimulation in lampreys. Soc. Neurosci. Abstr. 25: 1906.

Cazalets, J. R., Sqalli-Houssaini, Y., and Clarac, F. (1992). Activation of the central pattern generators for locomotion by serotonin and excitatory amino acids in neonatal rat. J. Physiol. 455, 187-204. doi: 10.1113/jphysiol.1992.sp 019296

Chang, S., Chung-Davidson, Y. W., Libants, S. V., Nanlohy, K. G., Kiupel, M., Brown, C. T., et al. (2013). The sea lamprey has a primordial accessory olfactory system. BMC Evol. Biol. 13:172. doi: 10.1186/1471-2148-13-172

Chau, C., Giroux, N., Barbeau, H., Jordan, L., and Rossignol, S. (2002). Effects of intrathecal glutamatergic drugs on locomotion I. NMDA in short-term spinal cats. J. Neurophysiol. 88, 3032-3045. doi: 10.1152/jn.00138.2002

Christenson, J., Boman, A., Lagerbäck, P. A., and Grillner, S. (1988). The dorsal cell, one class of primary sensory neuron in the lamprey spinal cord. I. Touch, 
pressure but nonociception-a physiological study. Brain Res. 440, 1-8. doi: 10. 1016/0006-8993(88)91152-3

Christenson, J., Franck, J., and Grillner, S. (1989). Increase in endogenous 5-hydroxytryptamine levels modulates the central network underlying locomotion in the lamprey spinal cord. Neurosci. Lett. 100, 188-192. doi: 10. 1016/0304-3940(89)90682-4

Clarke, J. D., and Roberts, A. (1984). Interneurones in the Xenopus embryo spinal cord: sensory excitation and activity during swimming. J. Physiol. 354, 345-362. doi: 10.1113/jphysiol.1984.sp015380

Cohen, A. H., and Wallén, P. (1980). The neuronal correlate of locomotion in fish. "Fictive swimming" induced in an in vitro preparation of the lamprey spinal cord. Exp. Brain Res. 41, 11-18. doi: 10.1007/bf00236674

Cruce, W. L. R., and Newman, D. B. (1984). Evolution of motor systems: the reticulospinal pathways. Amer. Zool. 24, 733-753. doi: 10.1093/icb/24.3.733

Daghfous, G., Green, W. W., Zielinski, B. S., and Dubuc, R. (2012). Chemosensoryinduced motor behaviors in fish. Curr. Opin. Neurobiol. 22, 223-230. doi: 10. 1016/j.conb.2011.10.009

Dale, N., and Roberts, A. (1984). Excitatory amino acid receptors in Xenopus embryo spinal cord and their role in the activation of swimming. J. Physiol. 348, 527-543. doi: 10.1113/jphysiol.1984.sp015123

Dale, N., and Roberts, A. (1985). Dual-component amino-acid-mediated synaptic potentials: excitatory drive for swimming in Xenopus embryos. J. Physiol. 363, 35-59. doi: 10.1113/jphysiol.1985.sp015694

Davis, G. R., Jr., and McClellan, A. D. (1994a). Long distance axonal regeneration of identified lamprey reticulospinal neurons. Exp. Neurol. 127, 94-105. doi: 10. 1006/exnr.1994.1083

Davis, G. R., Jr., and McClellan, A. D. (1994b). Extent and time course of restoration of descending brainstem projections in spinal cord-transected lamprey. J. Comp. Neurol. 344, 65-82. doi: 10.1002/cne.903440106

Del Negro, C. A., Morgado-Valle, C., and Feldman, J. L. (2002). Respiratory rhythm: an emergent network property? Neuron 34, 821-830. doi: 10 . 1016/S0896-6273(02)00712-2

Derjean, D., Moussaddy, A., Atallah, E., St-Pierre, M., Auclair, F., Chang, S., et al. (2010). A novel neural substrate for the transformation of olfactory inputs into motor output. PLoS Biol. 8:e1000567. doi: 10.1371/journal.pbio.10 00567

Di Pasquale, E., Lindsay, A., Feldman, J., Monteau, R., and Hilaire, G. (1997). Serotonergic inhibition of phrenic motoneuron activity: an in vitro study in neonatal rat. Neurosci. Lett. 230, 29-32. doi: 10.1016/s0304-3940(97) 00469-2

Douglas, J. R., Noga, B. R., Dai, X., and Jordan, L. M. (1993). The effects of intrathecal administration of excitatory amino acid agonists and antagonists on the initiation of locomotion in the adult cat. J. Neurosci. 13, 990-1000.

Døving, K. B., and Selset, R. (1980). Behavior patterns in cod released by electrical stimulation of olfactory tract bundlets. Science 207, 559-560. doi: 10 . $1126 /$ science. 7352272

Dubuc, R., Bongianni, F., Ohta, Y., and Grillner, S. (1993a). Dorsal root and dorsal column mediated synaptic inputs to reticulospinal neurons in lampreys: involvement of glutamatergic, glycinergic, and GABAergic transmission. J. Comp. Neurol. 327, 251-259. doi: 10.1002/cne.903270207

Dubuc, R., Bongianni, F., Ohta, Y., and Grillner, S. (1993b). Anatomical and physiological study of brainstem nuclei relaying dorsal column inputs in lampreys. J. Comp. Neurol. 327, 260-270. doi: 10.1002/cne.903270208

Dubuc, R., Brocard, F., Antri, M., Fenelon, K., Gariépy, J.-F., Smetana, R., et al. (2008). Initiation of locomotion in lampreys. Brain Res. Rev. 57, 172-182. doi: 10.1016/j.brainresrev.2007.07.016

Dunbar, M. J., Tran, M. A., and Whelan, P. J. (2010). Endogenous extracellular serotonin modulates the spinal locomotor network of the neonatal mouse. J. Physiol. 588, 139-156. doi: 10.1113/jphysiol.2009.177378

Duysens, J. (1977). Reflex control of locomotion as revealed by stimulation ofcutaneous afferents in spontaneously walking premammillary cats. J. Neurophysiol. 40, 737-751.

Eidelberg, E., Walden, J. G., and Nguyen, L. H. (1981). Locomotor control in macaque monkeys. Brain 104, 647-663. doi: 10.1093/brain/104.4.647-a

El Manira, A., Pombal, M. A., and Grillner, S. (1997). Diencephalic projection to reticulospinal neurons involved in the initiation of locomotion in adult lampreys Lampetra fluviatilis. J. Comp. Neurol. 389, 603-616. doi: 10. 1002/(sici)1096-9861(19971229)389:4<603::aid-cne5>3.3.co;2-f
El Manira, A., Tegnér, J., and Grillner, S. (1994). Calcium-dependent potassium channels play a critical role for burst termination in the locomotor network in lamprey. J. Neurophysiol. 72, 1852-1861.

El-Yassir, N., Fleetwood-Walker, S. M., and Mitchell, R. (1988). Heterogeneous effects of serotonin in the dorsal horn of rat: the involvement of 5-HT1 receptor subtypes. Brain Res. 456, 147-158. doi: 10.1016/0006-8993(88)90356-3

Fady, J. C., Jamon, M., and Clarac, F. (1998). Early olfactory-induced rhythmic limb activity in the newborn rat. Brain Res. Dev. Brain Res. 108, 111-123. doi: 10.1016/s0165-3806(98)00040-6

Fahrenholz, C. (1936). Die sensiblen Einrichtungen der Neunaugenhaut. $Z$. Mikrosk Anat. Forsch. 40, 323-380.

Frigon, A., Thibaudier, Y., Johnson, M. D., Heckman, C. J., and Hurteau, M. F. (2012). Cutaneous inputs from the back abolish locomotor-like activity and reduce spastic-like activity in the adult cat following complete spinal cord injury. Exp. Neurol. 235, 588-598. doi: 10.1016/j.expneurol.2012.03.013

Frontini, A., Zaidi, A. U., Hua, H., Wolak, T. P., Greer, C. A., Kafitz, K. W., et al. (2003). Glomerular territories in the olfactory bulb from the larval stage of the sea lamprey Petromyzon marinus. J. Comp. Neurol. 465, 27-37. doi: 10. 1002/cne.10811

Garcia-Rill, E., and Skinner, R. D. (1987a). The mesencephalic locomotor region. I. Activation of a medullary projection site. Brain Res. 411, 1-12. doi: 10 1016/0006-8993(87)90675-5

Garcia-Rill, E., and Skinner, R. D. (1987b). The mesencephalic locomotor region. II. Projections to reticulospinal neurons. Brain Res. 411, 13-20. doi: 10. 1016/0006-8993(87)90676-7

Garcia-Rill, E., Skinner, R. D., Conrad, C., Mosley, D., and Campbell, C. (1986). Projections of the mesencephalic locomotor region in the rat. Brain Res. Bull. 17, 33-40. doi: 10.1016/0361-9230(86)90158-9

Garraway, S. M., and Hochman, S. (2001). Modulatory actions of serotonin, norepinephrine, dopamine, and acetylcholine in spinal cord deep dorsal horn neurons. J. Neurophysiol. 86, 2183-2194.

Gelman, S., Ayali, A., Tytell, E. D., and Cohen, A. H. (2007). Larval lampreys possess a functional lateral line system. J. Comp. Physiol. A Neuroethol. Sens. Neural Behav. Physiol. 193, 271-277. doi: 10.1007/s00359-006-0183-9

Gerachshenko, T., Blackmer, T., Yoon, E.-J., Bartleson, C., Hamm, H. E., and Alford, S. (2005). Gbetagamma acts at the C terminus of SNAP-25 to mediate presynaptic inhibition. Nat. Neurosci. 8, 597-605. doi: 10.1038/nn1439

Gerachshenko, T., Schwartz, E., Bleckert, A., Photowala, H., Seymour, A., and Alford, S. (2009). Presynaptic G-protein-coupled receptors dynamically modify vesicle fusion, synaptic cleft glutamate concentrations and motor behavior. J. Neurosci. 29, 10221-10233. doi: 10.1523/JNEUROSCI.1404-09.2009

Green, W. W., Basilious, A., Dubuc, R., and Zielinski, B. S. (2013). The neuroanatomical organization of projection neurons associated with different olfactory bulb pathways in the sea lamprey, Petromyzon marinus. PLoS One 8:e69525. doi: 10.1371/journal.pone.0069525

Grillner, S. (1985). Neurobiological bases of rhythmic motor acts in vertebrates. Science 228, 143-149. doi: 10.1126/science.3975635

Grillner, S., Deliagina, T., Ekeberg, O., El Manira, A., Hill, R. H., Lansner, A., et al. (1995). Neural networks that co-ordinate locomotion and body orientation in lamprey. Trends Neurosci. 18, 270-279. doi: 10.1016/0166-2236(95) 93914-j

Grillner, S., Ekeberg, O., El Manira, A., Lansner, A., Parker, D., Tegnér, J., et al. (1998a). Intrinsic function of a neuronal network-a vertebrate central pattern generator. Brain Res. Brain Res. Rev. 26, 184-197. doi: 10.1016/s01650173(98)00002-2

Grillner, S., Parker, D., and El Manira, A. (1998b). Vertebrate locomotion-a lamprey perspective. Ann. N Y Acad. Sci. 860, 1-18. doi: 10.1111/j.1749-6632. 1998.tb09035.x

Grillner, S., McClellan, A., Sigvardt, K., Wallén, P., and Wilén, M. (1981). Activation of NMDA-receptors elicits "fictive locomotion" in lamprey spinal cord in vitro. Acta Physiol. Scand. 113, 549-551. doi: 10.1111/j.1748-1716.1981. tb06937.x

Grillner, S., and Wallén, P. (1980). Does the central pattern generation for locomotion in lamprey depend on glycine inhibition? Acta Physiol. Scand. 110, 103-105. doi: 10.1111/j.1748-1716.1980.tb06637.x

Grillner, S., and Wallén, P. (2002). Cellular bases of a vertebrate locomotor systemsteering, intersegmental and segmental co-ordination and sensory control. Brain Res. Brain Res. Rev. 40, 92-106. doi: 10.1016/s0165-0173(02)00193-5 
Grillner, S., Wallén, P., Saitoh, K., Kozlov, A., and Robertson, B. (2008). Neural bases of goal-directed locomotion in vertebrates-an overview. Brain Res. Rev. 57, 2-12. doi: 10.1016/j.brainresrev.2007.06.027

Grimm, R. J. (1960). Feeding behavior and electrical stimulation of the brain of Carassius auratus. Science 131, 162-163. doi: 10.1126/science.131.3394.162

Guertin, P. A., and Hounsgaard, J. (1998). NMDA-Induced intrinsic voltage oscillations depend on L-type calcium channels in spinal motoneurons of adult turtles. J. Neurophysiol. 80, 3380-3382.

Hagelin, L. O., and Johnels, A. G. (1955). On the structure and function of the accessory olfactory organ in lampreys. Acta Zool. 36, 113-125. doi: 10.1111/j. 1463-6395.1955.tb00376.x

Hägglund, M., Borgius, L., Dougherty, K. J., and Kiehn, O. (2010). Activation of groups of excitatory neurons in the mammalian spinal cord or hindbrain evokes locomotion. Nat. Neurosci. 13, 246-252. doi: 10.1038/nn.2482

Hansen, A., and Zielinski, B. S. (2005). Diversity in the olfactory epithelium of bonyfishes: development, lamellar arrangement, sensory neuron cell types andtransduction component. J. Neurocytol. 34, 183-208. doi: 10.1007/s11068005-8353-1

Harris-Warrick, R. M., and Cohen, A. H. (1985). Serotonin modulates the central pattern generator for locomotion in the isolated lamprey spinal cord. J. Exp. Biol. 116, 27-46.

Hasler, A. D., and Wisby, W. J. (1951). Discrimination of stream odors by fishes and its relation to parent stream behavior. Am. Nat. 135, 223-238. doi: 10. $1086 / 281672$

Headley, P. M., Duggan, A. W., and Griersmith, B. T. (1978). Selective reduction by noradrenaline and 5-hydroxytryptamine of nociceptive responses of cat dorsal horn neurones. Brain Res. 145, 185-189. doi: 10.1016/0006-8993(78)90809-0

Hellgren, J., Grillner, S., and Lansner, A. (1992). Computer simulation of the segmental neural network generating locomotion in lamprey by using populations of network interneurons. Biol. Cybern. 68, 1-13. doi: 10. 1007/bf00203132

Hilaire, G., Bou, C., and Monteau, R. (1997). Serotonergic modulation of central respiratory activity in the neonatal mouse: an in vitro study. Eur. J. Pharmacol. 329, 115-120. doi: 10.1016/s0014-2999(97)89173-x

Hill, R., Matsushima, T., Schotland, J., and Grillner, S. (1992). Apamin blocks the slow AHP in lamprey and delays termination of locomotor bursts. Neuroreport 3, 943-945. doi: 10.1097/00001756-199210000-00032

Hill, R. H., Svensson, E., Dewael, Y., and Grillner, S. (2003). 5-HT inhibits $\mathrm{N}$-type but not $\mathrm{L}$-type $\mathrm{Ca}(2+)$ channels via 5 -HT1A receptors in lamprey spinal neurons. Eur. J. Neurosci. 18, 2919-2924. doi: 10.1111/j.1460-9568.2003. 03051.x

Hochman, S., Jordan, L. M., and MacDonald, J. F. (1994a). N-methyl-D-aspartate receptor-mediated voltage oscillations in neurons surrounding the central canal in slices of rat spinal cord. J. Neurophysiol. 72, 565-577.

Hochman, S., Jordan, L. M., and Schmidt, B. J. (1994b). TTX-resistant NMDA receptor-mediated voltage oscillations in mammalian lumbar motoneurons. J. Neurophysiol. 72, 2559-2562.

Hounsgaard, J., and Kiehn, O. (1985). Ca++ dependent bistability induced by serotonin in spinal motoneurons. Exp. Brain Res. 57, 422-425. doi: 10. 1007/bf00236551

Johnson, N. S., Yun, S. S., Thompson, H. T., Brant, C. O., and Li, W. (2009). A synthetized pheromone induces upstream movement in female sea lamprey and summons them into traps. Proc. Natl. Acad. Sci. U S A 106, 1021-1026. doi: 10.1073/pnas.0808530106

Jordan, L. M. (1986). "Initiation of locomotion from the mammalian brainstem," in Neurobiology of Vertebrate Locomotion, eds S. Grillner, P. S. G. Stein, D. G. Stuart, H. Forssberg, and R. M. Herman (London: Macmillan Press), 21-37.

Jordan, L. M., McVagh, J. R., Noga, B. R., Cabaj, A. M., Majczyński, H., Sławińska, U., et al. (2014). Cholinergic mechanisms in spinal locomotion-potential target for rehabilitation approaches. Front. Neural Circuits 8:132. doi: 10.3389/fncir. 2014.00132

Kimmel, C. B., Powell, S. L., and Metcalfe, W. K. (1982). Brain neurons which project to the spinal cord in young larvae of the zebrafish. J. Comp. Neurol. 205, 112-127. doi: 10.1002/cne.902050203

Kimura, Y., Satou, C., Fujioka, S., Shoji, W., Umeda, K., Ishizuka, T., et al. (2013). Hindbrain V2a neurons in the excitation of spinal locomotor circuits during zebrafish swimming. Curr. Biol. 23, 843-849. doi: 10.1016/j.cub.2013.03.066

Kudo, N., and Yamada, T. (1987). N-methyl-D, L-aspartate-induced locomotor activity in a spinal cord-hindlimb muscles preparation of the newborn rat studied in vitro. Neurosci. Lett. 75, 43-48. doi: 10.1016/0304-3940(87) 90072-3

Laframboise, A. J., Ren, X., Chang, S., Dubuc, R., and Zielinski, B. S. (2007). Olfactory sensory neurons in the sea lamprey display polymorphisms. Neurosci. Lett. 414, 277-281. doi: 10.1016/j.neulet.2006.12.037

Lansner, A., and Ekeberg, O. (1994). Neuronal network models of motor generation and control. Curr. Opin. Neurobiol. 4, 903-908. doi: 10.1016/09594388(94)90140-6

Leach, J. (1951). The hypophysis of lampreys in relation to the nasal apparatus. J. Morphol. 89, 217-255. doi: 10.1002/jmor.1050890203

Le Ray, D., Brocard, F., Bourcier-Lucas, C., Auclair, F., Lafaille, P., and Dubuc, R. (2003). Nicotinic activation of reticulospinal cells involved in the control of swimming in lampreys. Eur. J. Neurosci. 17, 137-148. doi: 10.1046/j.1460-9568. 2003.02417.x

Le Ray, D., Juvin, L., Boutin, T., Auclair, F., and Dubuc, R. (2010). A neuronal substrate for a state-dependent modulation of sensory inputs in the brainstem. Eur. J. Neurosci. 32, 53-59. doi: 10.1111/j.1460-9568.2010.07276.x

Le Ray, D., Juvin, L., Ryczko, D., and Dubuc, R. (2011). Supraspinal control of locomotion: the mesencephalic locomotor region. Prog. Brain Res. 188, 51-70. doi: 10.1016/B978-0-444-53825-3.00009-7

Lethbridge, R. C., and Potter, I. C. (1982). "The skin," in The Biology of Lampreys (Vol. III), eds M. S. Hardisty and I. C. Potter (New York: Academic Press), $377-448$.

Li, W., Sorensen, P. W., and Gallaher, D. D. (1995). The olfactory system of migratory adult sea lamprey (Petromyzon marinus) is specifically and acutely sensitive to unique bile acids released by conspecific larvae. J. Gen. Physiol. 105, 569-587. doi: 10.1085/jgp.105.5.569

Lindsay, A. D., and Feldman, J. L. (1993). Modulation of respiratory activity of neonatal rat phrenic motoneurones by serotonin. J. Physiol. 461, 213-233. doi: 10.1113/jphysiol.1993.sp019510

Liu, J., and Jordan, L. M. (2005). Stimulation of the parapyramidal region of the neonatal rat brain stem produces locomotor-like activity involving spinal 5-HT7 and 5-HT2A receptors. J. Neurophysiol. 94, 1392-1404. doi: 10.1152/jn. 00136.2005

Lopez-Garcia, J. A. (1998). Serotonergic modulation of the responses to excitatory amino acids of rat dorsal horn neurons in vitro: implications for somatosensory transmission. Eur. J. Neurosci. 10, 1341-1349. doi: 10.1046/j.1460-9568.1998. 00153.x

Lopez-Garcia, J. A., and King, A. E. (1996). Pre- and post-synaptic actions of 5 -hydroxytryptamine in the rat lumbar dorsal horn in vitro: implications for somatosensory transmission. Eur. J. Neurosci. 8, 2188-2197. doi: 10.1111/j. 1460-9568.1996.tb00740.x

MacLean, J. N., Cowley, K. C., and Schmidt, B. J. (1998). NMDA receptormediated oscillatory activity in the neonatal rat spinal cord is serotonin dependent. J. Neurophysiol. 79, 2804-2808.

MacLean, J. N., and Schmidt, B. J. (2001). Voltage-sensitivity of motoneuron NMDA receptor channels is modulated by serotonin in the neonatal rat spinal cord. J. Neurophysiol. 86, 1131-1138.

Marder, E. (1994). Invertebrate neurobiology. Polymorphic neural networks. Curr. Biol. 4, 752-754. doi: 10.1016/s0960-9822(00)00169-x

Marder, E., and Thirumalai, V. (2002). Cellular, synaptic and network effects of neuromodulation. Neural Netw. 15, 479-493. doi: 10.1016/s08936080(02)00043-6

Marlinsky, V. V., and Voitenko, L. P. (1991). The effect of procaine injection into the medullary reticular formation on forelimb muscle activity evoked by mesencephalic locomotor region and vestibular stimulation in the decerebrated guinea-pig. Neuroscience 45, 753-759. doi: 10.1016/0306-4522(91) 90287-x

Martin, A. R., and Wickelgren, W. O. (1971). Sensory cells in the spinal cord of the sea lamprey. J. Physiol. 212, 65-83. doi: 10.1113/jphysiol.1971.sp009310

Masino, M. A., Abbinanti, M. D., Eian, J., and Harris-Warrick, R. M. (2012). TTX-resistant NMDA receptor-mediated membrane potential oscillations in neonatal mouse Hb9 interneurons. PLoS One 7:e47940. doi: 10.1371/journal. pone. 0047940

Matthews, G., and Wickelgren, W. O. (1978). Trigeminal sensory neurons of the sea lamprey. J. Comp. Physiol. 123, 329-333. doi: 10.1007/bf00656966

McClellan, A. D. (1988). Brainstem command systems for locomotion in the lamprey: localization of descending pathways in the spinal cord. Brain Res. 457, 338-349. doi: 10.1016/0006-8993(88)90704-4 
McClellan, A. D., and Grillner, S. (1984). Activation of "fictive swimming" by electrical microstimulation of brainstem locomotor regions in an in vitro preparation of the lamprey central nervous system. Brain Res. 300, 357-361. doi: 10.1016/0006-8993(84)90846-1

Meer, D. P., and Buchanan, J. T. (1992). Apamin reduces the late afterhyperpolarization of lamprey spinal neurons, with little effect on fictive swimming. Neurosci. Lett. 143, 1-4. doi: 10.1016/0304-3940(92)90219-w

Ménard, A., Auclair, F., Bourcier-Lucas, C., Grillner, S., and Dubuc, R. (2007). GABAergic projections to the mesencephalic locomotor region in the lamprey Petromyzon marinus. J. Comp. Neurol. 501, 260-273. doi: 10.1002/cne.21258

Musienko, P. E., Zelenin, P. V., Lyalka, V. F., Orlovsky, G. N., and Deliagina, T. G. (2008). Postural performance in decerebrated rabbit. Behav. Brain Res. 190, 124-134. doi: 10.1016/j.bbr.2008.02.011

Nanou, E., Alpert, M. H., Alford, S., and El Manira, A. (2013). Differential regulation of synaptic transmission by pre- and postsynaptic SK channels in the spinal locomotor network. J. Neurophysiol. 109, 3051-3059. doi: 10.1152/jn. 00067.2013

Nieuwenhuys, R. (1972). Topological analysis of the brain stem of the lamprey Lampetra fluviatilis. J. Comp. Neurol. 145, 165-177. doi: 10.1002/cne. 901450204

Nieuwenhuys, R. (1977). The brain of the lamprey in a comparative perspective. Ann. N Y Acad. Sci. 299, 97-145. doi: 10.1111/j.1749-6632.1977.tb41902.x

Nieuwenhuys, R. (2011). The structural, functional and molecular organization of the brainstem. Front. Neuroanat. 5:33. doi: 10.3389/fnana.2011.00033

Nieuwenhuys, R., and Nicholson, C. (1998). "Lampreys, petromyzontidae," in The Central Nervous System of Vertebrates (Vol. 1), eds R. Nieuwenhuys, H. J. ten Donkelaar, and C. Nicholson (Berlin: Springer), 397-496.

Noga, B. R., Kriellaars, D. J., Brownstone, R. M., and Jordan, L. M. (2003). Mechanism for activation of locomotor centers in the spinal cord by stimulation of the mesencephalic locomotor region. J. Neurophysiol. 90, 1464-1478. doi: 10.1152/jn.00034.2003

Northcutt, R. G. (1979). Experimental determination of the primary trigeminal projections in lampreys. Brain Res. 163, 323-327. doi: 10.1016/00068993(79)90360-3

Northcutt, R. G., and Puzdrowski, R. L. (1988). Projections of the olfactory bulb and nervus terminalis in the silver lamprey. Brain Behav. Evol. 32, 96-107. doi: 10.1159/000116537

Ohta, Y., and Grillner, S. (1989). Monosynaptic excitatory amino acid transmission from the posterior rhombencephalic reticular nucleus to spinal neurons involved in the control of locomotion in lamprey. J. Neurophysiol. 62, 1079-1089.

Orlovskiı̌, G. N. (1970a). [Relations between reticulo-spinal neurons and locomotor regions of the brain stem]. Biofizika 15, 171-178.

Orlovskiı̆, G. N. (1970b). [Work of reticulo-spinal neurons during locomotion]. Biofizika 15, 728-737.

Orlovskiı̌, G. N. (1972). The effect of different descending systems on flexor and extensor activity during locomotion. Brain Res. 40, 359-371. doi: 10.1016/00068993(72)90139-4

Ovsepian, S. V., and Vesselkin, N. P. (2006). Serotonergic modulation of synaptictransmission and action potential firing in frog motoneurons. Brain Res. 1102, 71-77. doi: 10.1016/j.brainres.2006.04.035

Parker, D., and Grillner, S. (1999). Activity-dependent metaplasticity of inhibitory and excitatory synaptic transmission in the lamprey spinal cord locomotor network. J. Neurosci. 19, 1647-1656.

Parker, D., and Grillner, S. (2000). Neuronal mechanisms of synaptic and network plasticity in the lamprey spinal cord. Prog. Brain Res. 125, 381-398. doi: 10. 1016/s0079-6123(00)25027-9

Pearlstein, E., Ben Mabrouk, F., Pflieger, J. F., and Vinay, L. (2005). Serotonin refines the locomotor-related alternations in the in vitro neonatal rat spinal cord. Eur. J. Neurosci. 21, 1338-1346. doi: 10.1111/j.1460-9568.2005. 03971.x

Perreault, M. C., and Glover, J. C. (2013). Glutamatergic reticulospinal neurons in the mouse: developmental origins, axon projections and functional connectivity. Ann. N Y Acad. Sci. 1279, 80-89. doi: 10.1111/nyas. 12054

Perrier, J. F., Alaburda, A., and Hounsgaard, J. (2003). 5-HT1A receptors increase excitability of spinal motoneurons by inhibiting a TASK-1-like $\mathrm{K}+$ current in the adult turtle. J. Physiol. 548, 485-492. doi: 10.1111/j.1469-7793.2003. 00485.x
Perrier, J. F., and Cotel, F. (2015). Serotonergic modulation of spinal motor control. Curr. Opin. Neurobiol. 33, 1-7. doi: 10.1016/j.conb.2014. 12.008

Petzold, G. C., Hagiwara, A., and Murthy, V. N. (2009). Serotonergic modulation of odor input to the mammalian olfactory bulb. Nat. Neurosci. 12, 784-791. doi: $10.1038 / \mathrm{nn} .2335$

Pflieger, J. F., and Dubuc, R. (2004). Vestibulo-reticular projections in adult lamprey: their role in locomotion. Neuroscience 129, 817-829. doi: 10.1016/j. neuroscience.2004.08.025

Photowala, H., Blackmer, T., Schwartz, E., Hamm, H. E., and Alford, S. (2006). $\mathrm{G}$ protein betagamma-subunits activated by serotonin mediate presynaptic inhibition by regulating vesicle fusion properties. Proc. Natl. Acad. Sci. U S A 103, 4281-4286. doi: 10.1073/pnas.0600509103

Pierre, J., Reperant, J., Ward, R., Vesselkin, N. P., Rio, J. P., Miceli, D., et al. (1992). The serotoninergic system of the brain of the lamprey, Lampetra fluviatilis: an evolutionary perspective. J. Chem. Neuroanat. 5, 195-219. doi: 10.1016/08910618(92)90046-s

Ren, X., Chang, S., Laframboise, A., Green, W., Dubuc, R., and Zielinski, B. (2009). Projections from the accessory olfactory organ into the medial region of the olfactory bulb in the sea lamprey (Petromyzon marinus): a novel vertebrate sensory structure? J. Comp. Neurol. 516, 105-116. doi: 10.1002/cne. 22100

Roberts, A., and Alford, S. (1986). Descending projections and excitation during fictive swimming in Xenopus embryos: neuroanatomy and lesion experiments. J. Comp. Neurol. 250, 253-261. doi: 10.1002/cne.902500212

Robertson, B., Kardamakis, A., Capantini, L., Pérez-Fernández, J., Suryanarayana, S. M., Wallén, P., et al. (2014). The lamprey blueprint of the mammalian nervous system. Prog. Brain Res. 212, 337-349. doi: 10.1016/b978-0-444-634887.00016-1

Ronan, M., and Northcutt, R. G. (1990). Projections ascending from the spinal cord to the brain in petromyzontid and myxinoid agnathans. J. Comp. Neurol. 291, 491-508. doi: 10.1002/cne.902910402

Roseberry, T. K., Lee, A. M., Lalive, A. L., Wilbrecht, L., Bonci, A., and Kreitzer, A. C. (2016). Cell-type-specific control of brainstem locomotor circuits by basal ganglia. Cell 164, 526-537. doi: 10.1016/j.cell.2015.12.037

Rossignol, S., Dubuc, R., and Gossard, J. P. (2006). Dynamic sensorimotor interactions in locomotion. Physiol. Rev. 86, 89-154. doi: 10.1152/physrev. 00028.2005

Rovainen, C. M. (1967). Physiological and anatomical studies on large neurons of central nervous system of the sea lamprey (Petromyzon marinus) I. Müller and Mauthner cells. J. Neurophysiol. 30, 1000-1023.

Rovainen, C. M. (1974). Synaptic interactions of reticulospinal neurons and nerve cells in the spinal cord of the sea lamprey. J. Comp. Neurol. 154, 207-224. doi: 10.1002/cne.901540207

Rovainen, C. M., and Yan, Q. (1985). Sensory responses of dorsal cells in the lamprey brain. J. Comp. Physiol. A. 156, 181-183. doi: 10.1007/bf00 610859

Rybak, I. A., Shevtsova, N. A., Lafreniere-Roula, M., and McCrea, D. A. (2006). Modelling spinal circuitry involved in locomotor pattern generation: insights from deletions during fictive locomotion. J. Physiol. 577, 617-639. doi: 10 1113/jphysiol.2006.118703

Ryczko, D., Auclair, F., Cabelguen, J. M., and Dubuc, R. (2016). The mesencephalic locomotor region sends a bilateral glutamatergic drive to hindbrain reticulospinal neurons in a tetrapod. J. Comp. Neurol. 524, 1361-1383. doi: 10.1002/cne.23911

Ryczko, D., and Dubuc, R. (2013). The multifunctional mesencephalic locomotor region. Curr. Pharm. Des. 19, 4448-4470. doi: 10.2174/13816128113192 40011

Ryczko, D., Grätsch, S., Auclair, F., Dubé, C., Bergeron, S., Alpert, M. H., et al. (2013). Forebrain dopamine neurons project down to a brainstem region controlling locomotion. Proc. Natl. Acad. Sci. U S A 110, E3235-E3242. doi: 10. 1073/pnas.1301125110

Schmidt, B. J., Hochman, S., and MacLean, J. N. (1998). NMDA receptor-mediated oscillatory properties: potential role in rhythm generation in the mammalian spinal cord. Ann. N Y Acad. Sci. 860, 189-202. doi: 10.1111/j.1749-6632.1998. tb09049.x

Schmidt, B. J., and Jordan, L. M. (2000). The role of serotonin in reflex modulation and locomotor rhythm production in the mammalian spinal cord. Brain Res. Bull. 53, 689-710. doi: 10.1016/s0361-9230(00)00402-0 
Schotland, J. L., and Grillner, S. (1993). Effects of serotonin on fictive locomotion coordinated by a neural network deprived of NMDA receptormediated cellular properties. Exp. Brain Res. 93, 391-398. doi: 10.1007/bf002 29355

Schotland, J. L., Shupliakov, O., Grillner, S., and Brodin, L. (1996). Synaptic and nonsynaptic monoaminergic neuron systems in the lamprey spinal cord. J. Comp. Neurol. 372, 229-244. doi: 10.1002/(sici)10969861(19960819)372:2<229::aid-cne6>3.0.co;2-5

Schwartz, E. J., Blackmer, T., Gerachshenko, T., and Alford, S. (2007). Presynaptic G-protein-coupled receptors regulate synaptic cleft glutamate via transient vesicle fusion. J. Neurosci. 27, 5857-5868. doi: 10.1523/jneurosci.1160-07. 2007

Schwartz, E. J., Gerachshenko, T., and Alford, S. (2005). 5-HT prolongs ventral root bursting via presynaptic inhibition of synaptic activity during fictive locomotion in lamprey. J. Neurophysiol. 93, 980-988. doi: 10.1152/jn.00669. 2004

Scott, W. B. (1887). Notes on the development of Petromyzon. J. Morphol. 1, 253-310. doi: 10.1002/jmor.1050010203

Shefchyk, S. J., Jell, R. M., and Jordan, L. M. (1984). Reversible cooling of the brainstem reveals areas required for mesencephalic locomotor region evoked treadmill locomotion. Exp. Brain Res. 56, 257-262. doi: 10.1007/bf00 236281

Shik, M. L., Severin, F. V., and Orlovskiǐ , G. N. (1966). [Control of walking and running by means of electric stimulation of the midbrain]. Biofizika 11, 659-666.

Shupliakov, O., Pieribone, V. A., Gad, H., and Brodin, L. (1995). Synaptic vesicle depletion in reticulospinal axons is reduced by 5 -hydroxytryptamine: direct evidence for presynaptic modulation of glutamatergic transmission. Eur. J. Neurosci. 7, 1111-1116. doi: 10.1111/j.1460-9568.1995.tb 01099.x

Sigvardt, K. A., Grillner, S., Wallén, P., and Van Dongen, P. A. (1985). Activation of NMDA receptors elicits fictive locomotion and bistable membrane properties in the lamprey spinal cord. Brain Res. 336, 390-395. doi: 10. 1016/0006-8993(85)90676-6

Sillar, K. T., Reith, C. A., and McDearmid, J. R. (1998). Development and aminergic neuromodulation of a spinal locomotor network controlling swimming in Xenopus larvae. Ann. N Y Acad. Sci. 860, 318-332. doi: 10.1111/j. 1749-6632.1998.tb09059.x

Sillar, K. T., and Simmers, A. J. (1994). Presynaptic inhibition of primary afferent transmitter release by 5 -hydroxytryptamine at a mechanosensory synapse in the vertebrate spinal cord. J. Neurosci. 14, 2636-2647.

Sirota, M. G., Viana Di Prisco, G., and Dubuc, R. (2000). Stimulation of the mesencephalic locomotor region elicits controlled swimming in semi-intact lampreys. Eur. J. Neurosci. 12, 4081-4092. doi: 10.1046/j.1460-9568.2000. 00301.x

Skagerberg, G., and Björklund, A. (1985). Topographic principles in the spinal projections of serotonergic and non-serotonergic brainstem neurons in the rat. Neuroscience 15, 445-480. doi: 10.1016/0306-4522(85)90225-8

Skinner, R. D., and Garcia-Rill, E. (1984). The mesencephalic locomotor region (MLR) in the rat. Brain Res. 323, 385-389. doi: 10.1016/0006-8993(84) 90319-6

Sławińska, U., Miazga, K., and Jordan, L. M. (2014). 5- $\mathrm{HT}_{2}$ and 5- $\mathrm{HT}_{7}$ receptor agonists facilitate plantar stepping in chronic spinal rats through actions on different populations of spinal neurons. Front. Neural Circuits 8:95. doi: 10. 3389/fncir.2014.00095

Smetana, R., Alford, S., and Dubuc, R. (2007). Muscarinic receptor activation elicits sustained, recurring depolarizations in reticulospinal neurons. J. Neurophysiol. 97, 3181-3192. doi: 10.1152/jn.00954.2006

Smetana, R., Juvin, L., Dubuc, R., and Alford, S. (2010). A parallel cholinergic brainstem pathway for enhancing locomotor drive. Nat. Neurosci. 13, 731-738. doi: $10.1038 / \mathrm{nn} .2548$

Steeves, J. D., and Jordan, L. M. (1984). Autoradiographic demonstration of the projections from the mesencephalic locomotor region. Brain Res. 307, 263-276. doi: 10.1016/0006-8993(84)90480-3

Steinbusch, H. W., Verhofstad, A. A., Penke, B., Vlarga, J., and Joosten, H. W. (1981). Immunohistochemical characterization of monoamine-containing neurons in the central nervous system by antibodies to serotonin and noradrenalin. A study in the rat and the lamprey (Lampetra fluviatilis). Acta Histochem. Suppl. 24, 107-122.
Svensson, E., Wikström, M. A., Hill, R. H., and Grillner, S. (2003). Endogenous and exogenous dopamine presynaptically inhibits glutamatergic reticulospinal transmission via an action of D2-receptors on N-type Ca2+ channels. Eur. J. Neurosci. 17, 447-454. doi: 10.1046/j.1460-9568.2003. 02466.x

Swain, G. P., Snedeker, J. A., Ayers, J., and Selzer, M. E. (1993). Cytoarchitecture of spinal-projecting neurons in the brain of the larval sea lamprey. J. Comp. Neurol. 336, 194-210. doi: 10.1002/cne.903360204

Takahashi, M., Freed, R., Blackmer, T., and Alford, S. (2001). Calcium influx-independent depression of transmitter release by 5 -HT at lamprey spinal cord synapses. J. Physiol. 532, 323-336. doi: 10.1111/j.1469-7793.2001. 0323f.x

ten Donkelaar, H. J., Bangma, G. C., Barbas-Henry, H. A., de Boer-van Huizen, R., and Wolters, J. G. (1987). The brain stem in a lizard, Varanus exanthematicus. Adv. Anat. Embryol. Cell. Biol. 107, 1-168.

Travagli, R. A., and Williams, J. T. (1996). Endogenous monoamines inhibit glutamate transmission in the spinal trigeminal nucleus of the guinea-pig. J. Physiol. 491, 177-185. doi: 10.1113/jphysiol.1996.sp021205

Varendi, H., and Porter, R. H. (2001). Breast odour as the only maternal stimulus elicits crawling towards the odour source. Acta Paediatr. 90, 372-375. doi: 10. 1080/08035250119715

Viala, G., Orsal, D., and Buser, P. (1978). Cutaneous fiber groups involved in the inhibition of fictive locomotion in the rabbit. Exp. Brain Res. 33, 257-267. doi: $10.1007 / \mathrm{bf} 00238064$

Viana Di Prisco, G., Boutin, T., Petropoulos, D., Brocard, F., and Dubuc, R. (2005). The trigeminal sensory relay to reticulospinal neurones in lampreys. Neuroscience 131, 535-546. doi: 10.1016/j.neuroscience.2004.11.003

Viana Di Prisco, G., Dubuc, R., and Grillner, S. (1994). 5-HT innervation of reticulospinal neurons and other brainstem structures in lamprey. J. Comp. Neurol. 342, 23-34. doi: 10.1002/cne.903420104

Viana Di Prisco, G., Ohta, Y., Bongianni, F., Grillner, S., and Dubuc, R. (1995). Trigeminal inputs to reticulospinal neurones in lampreys are mediated by excitatory and inhibitory amino acids. Brain Res. 695, 76-80. doi: 10 1016/0006-8993(95)00936-k

Viana Di Prisco, G., Pearlstein, É., Le Ray, D., Robitaille, R., and Dubuc, R. (2000). A cellular mechanism for the transformation of a sensory input into a motor command. J. Neurosci. 20, 8169-8176.

Viana Di Prisco, G., Pearlstein, É., Robitaille, R., and Dubuc, R. (1997). Sensoryevoked NMDA plateau potentials and their role in the initiation of locomotion. Science 278, 1122-1125. doi: 10.1126/Science278.5340.1122

Wallén, P., Buchanan, J. T., Grillner, S., Hill, R. H., Christenson, J., and Hökfelt, T. (1989a). Effects of 5-hydroxytryptamine on the afterhyperpolarization, spike frequency regulation and oscillatory membrane properties in lamprey spinal cord neurons. J. Neurophysiol. 61, 759-768.

Wallén, P., Christenson, J., Brodin, L., Hill, R., Lansner, A., and Grillner, S. (1989b). Mechanisms underlying the serotonergic modulation of the spinal circuitry for locomotion in lamprey. Prog. Brain Res. 80, 321-327; discussion 315-319. doi: 10.1016/s0079-6123(08)62227-x

Wallén, P., and Grillner, S. (1987). N-methyl-D-aspartate receptor-induced, inherent oscillatory activity in neurons active during fictive locomotion in the lamprey. J. Neurosci. 7, 2745-2755.

Wang, D., Grillner, S., and Wallén, P. (2014). Endogenous release of 5-HT modulates the plateau phase of NMDA-induced membrane potential oscillations in lamprey spinal neurons. J. Neurophysiol. 112, 30-38. doi: 10 1152/jn.00582.2013

Wells, C. A., Zurawski, Z., Betke, K. M., Yim, Y. Y., Hyde, K., Rodriguez, S., et al. (2012). G $\beta \gamma$ inhibits exocytosis via interaction with critical residues on soluble N-ethylmaleimide-sensitive factor attachment protein-25. Mol. Pharmacol. 82, 1136-1149. doi: 10.1124/mol.112.080507

Westberg, K. G., and Kolta, A. (2011). The trigeminal circuits responsible for chewing. Int. Rev. Neurobiol. 97, 77-98. doi: 10.1016/B978-0-12-385198-7. 00004-7

Whitear, M., and Lane, E. B. (1981). Fine structure of Merkel cells in lampreys. Cell Tissue Res. 220, 139-151. doi: 10.1007/bf00209973

Wickelgren, W. O. (1977). Physiological and anatomical characteristics of reticulospinalneurones in lamprey. J. Physiol. 270, 89-114. doi: 10. 1113/jphysiol.1977.sp011940

Wikström, M. A., and El Manira, A. (1998). Calcium influx through N- and P/Q-type channels activate apamin-sensitive calcium-dependent potassium 
channels generating the late afterhyperpolarization in lamprey spinal neurons. Eur. J. Neurosci. 10, 1528-1532. doi: 10.1046/j.1460-9568.1998. 00194.x

Wikström, M., Hil, R., Hellgren, J., and Grillner, S. (1995). The action of 5-HT on calcium-dependent potassium channels and on the spinal locomotor network in lamprey is mediated by 5-HT1A-like receptors. Brain Res. 678, 191-199. doi: 10.1016/0006-8993(95)00183-q

Wilson, J. M., Hartley, R., Maxwell, D. J., Todd, A. J., Lieberam, I., Kaltschmidt, J. A., et al. (2005). Conditional rhythmicity of ventral spinal interneurons defined by expression of the Hb9 homeodomain protein. J. Neurosci. 25, 5710-5719. doi: 10.1523/jneurosci.0274-05.2005

Yoon, E. J., Gerachshenko, T., Spiegelberg, B. D., Alford, S., and Hamm, H. E. (2007). Gbetagamma interferes with $\mathrm{Ca}^{2+}$-dependent binding of synaptotagmin to the soluble $\mathrm{N}$-ethylmaleimide-sensitive factor attachment protein receptor (SNARE) complex. Mol. Pharmacol. 72, 1210-1219. doi: 10. 1124/mol.107.039446
Zielinski, B. S., Moretti, N., Hua, H. N., Zaidi, A. U., and Bisaillon, A. D. (2000). Serotonergic nerve fibers in the primary olfactory pathway of the larval sea lamprey, Petromyzon marinus. J. Comp. Neurol. 420, 324-334. doi: 10. 1002/(sici)1096-9861(20000508)420:3<324::aid-cne4>3.0.co;2-6

Conflict of Interest Statement: The authors declare that the research was conducted in the absence of any commercial or financial relationships that could be construed as a potential conflict of interest.

Copyright (C) 2016 Daghfous, Green, Alford, Zielinski and Dubuc. This is an openaccess article distributed under the terms of the Creative Commons Attribution License (CC BY). The use, distribution and reproduction in other forums is permitted, provided the original author(s) or licensor are credited and that the original publication in this journal is cited, in accordance with accepted academic practice. No use, distribution or reproduction is permitted which does not comply with these terms. 